$$
\begin{aligned}
& \text { Tefsir Araştırmaları Dergisi } \\
& \text { مجلة الدر اسدات التفسيرية } \\
& \text { https://dergipark.org.tr/tr/pub/tader } \\
& \text { E-ISSN : 2587-0882 }
\end{aligned}
$$

Cilt/Volume: 5, Sayı/Issue: 1, Yıl/Year: 2021 (Nisan/April)

Sâmirî Kıssasıyla İlgili Tevrât'taki İfadelerin Müfessirlerin Yorumlarına Etkileri The Effects of The Expressions in the Torah of Sämirī Parable on Mufassirs' Commentaries

\title{
Selami YALÇIN
}

Dr. Öğr. Üyesi, Düzce Üniversitesi, İlahiyat Fakültesi, Temel İslam Bilimleri, Arap Dili ve Belagatı Anabilim Dalı Assistant professor, Düzce University, Faculty of Theology, Basic Islamic Sciences, Department of Arabic Language and Rhetoric Düzce, Turkey selamiyalcin@duzce.edu.tr https://orcid.org/0000-0002-9657-9103

Makale Bilgisi - Article Information Makale Türü/Article Type: Araştırma Makalesi/ Research Article Geliş Tarihi/Date Received: 11/10/2020 Kabul Tarihi/Date Accepted: 01/02/2021 Yayın Tarihi/Date Published: 30/05/2021

Atıf / Citation: Yalçın, Selami. "Sâmirî Kıssasıyla İlgili Tevrât'taki İfadelerin Müfessirlerin Yorumlarına Etkileri”. Tefsir Araştırmaları Dergisi 5/1 (Nisan/April 2021), 61-92 https://doi.org/ 10.31121/tader.808976

Intihal: Bu makale, $\checkmark$ iThenticate'yazılımınca taranmıştır. İntihal tespit edilmemiştir. Plagiarism: This article has been scanned by iThenticate. No plagiarism detected.

Copyright (C) Published by The Journal of Tafsīr Studies Sakarya/Turkey Bütün hakları saklıdır/All rights reserved. 
Öz

Hz. Mûsâ Tevrât’’ almak üzere kırk geceliğine Tûr-i Sinâ'ya çıktığında İsrâiloğulları Sâmirînnin yaptı̆̆1 altın buzağı heykeline tapmışlardı. Kur'ân'da birkaç sûrede bahsedilen kıssayla ilgili müfessirlerin bazen hem kendileriyle hem de Kur'ân'ın ifadeleriyle çelişen açıklamalarına rastlanılmaktadır. Bu makale bu çelişkilerin nereden kaynaklandığını tespit etmeyi hedeflemektedir. Kur'ân'da ve Tevrât'ta tafsilatlı olarak anlatılan bu kıssanın benzeşen ve ayrışan yönleri vardır. Makalede önce her iki kutsal kitapta anlatılan kıssa özetlenmiş, benzerliklerin ve farklılıkların analizi yapılmıştır. Sonra ayrışan noktaların müfessirlerin yorumları üzerindeki etkileri açıklanmıştır. Müfessirlerin bir müphemi veya Kur'ân'ın bahsetmediği bir hususu açılarken bazen Kur'ân'la örtüşmeyen veya onunla çelişen Tevrât'taki bazı ifadeleri kaynak belirtmeden tefsirlerine aktardıkları görülmüştür. Yapılan bu nakillerin kaynağının belirtilmemesi, takip eden asırlarda yazılan tefsirlerde çelişkilerin sürdürülmesine yol açmıştır. Ayrıca Hz. Ali (ra) ve İbn Abbâs'tan bu konuda nakledilen mevkûf rivâyetler de içerik olarak Kur'ân'la örtüşmemektedir. Müfessirlerin, tabiînden nakledilen rivâyetlerin kritiğini de pek yapmadıkları görülmektedir. Makalede hedeflenen bir diğer nokta ise bu tür kıssalar üzerinde de eleştirel çalışmaların yapılmasına katkı sağlamaktır.

Anahtar kelimeler: Tefsir, Kur'ân, Tevrât, Mûsâ, Sâmirî, Buzağı.

\section{Abstract}

When Moses (PBUH) went to Tûr-i Sinâ for forty nights to get the Torah, the Israelites started to worship the golden calf statue made by Sâmirî. This article aims to identify where these contradictions come from. This story, described in detail in the Quran and the Torah, has similar and divergent aspects. It is seen that the story is narrated in the Quran and the Torah in detail. In this article, firstly the story described in two holy books is summarized then similarities and differences are analyzed. Afterwards, the effects of the differential points on the mufassirs's commentaries are explained. It has been observed that the mufassirs quote some statements in the Torah, which sometimes contradict or do not overlap with the Qur'an, to their tafsir works without mentioning the source while explaining a vague point or a subject not mentioned by the Qur'an. Failure to state the source of these citations caused the continuance of contradictions in the tafsirs written in the following centuries. In addition, the mawquf narrations attributed to Ali ( $\mathrm{ra}$ ) and Ibn Abbās about this story do not overlap with the Qur'an in terms of content. It is also seen that the mufassirs do not criticize the narrations attributed to the tabi in sufficiently. Another point targeted in this article is to contribute to making critical studies on such stories.

Keywords: Tafsir, Qur'an, Torah, Moses, Sāmirī, Calf.

\section{Giriş}

Tefsirlerde, farklı sûrelerde zikredilen Sâmirî kıssası hakkında bazı müfessirlerin farklı açıklamalarda bulunmuş olması ve Kur'ân’la örtüşmeyen görüşler serdetmesi, bu fikirlerin kaynağını sorgulamayı gerektirmektedir. Kıssanın Kur'ân'ın muhtelif sûrelerinde ve Tevrât’’n farklı bölümlerinde geçmesi, kıssanın iki kutsal metindeki ifadelerinin karşılaştırılması ihtiyacını doğurmaktadır. İsrâiliyyâtın müfessirlerin başvurduğu bir kaynak olduğu gerçeğinden yola çıkarak Tevrât’ta geçen bu kıssanın tefsirlerde zikredilen yorumlara etkisinin araştırılması da önemli görülmektedir.

Bu makalede, birinci aşamada kıssanın Kur'ân'da ve Tevrât'ta geçen metinleri analiz edilecektir. İkinci aşamada benzerlikler ve farklılıklar ortaya çıkartılarak farklılıkların müfessirlerin yorumlarına etkileri araştırılacaktır. Özellikle bazı müfessirlerin kıssayı ele alırken Kur'ân'la örtüşmeyen yorumlarının Tevrât'tan kaynaklanan kısımları ortaya konulacaktır. Tarihi bir seyir izlenerek tefsirlerde, Tevrât'ın etkisinde kalınarak yapılan yorumların tahlili yapılacaktır. 
Kur'ân'da ve Tevrât'ta İsrâiloğullarının Mısır'dan çıkmaları, denizde boğulan Firavun ve ordusundan mucizelerle kurtulmaları; esaretten kurtulduktan sonra sık sık vefasızlık ve isyankârlık sergiledikleri ayrıntılı olarak anlatılmıştır. ${ }^{1}$ Sâmirî kıssası, onların zikzaklı psikolojik ve sosyolojik durumlarını en net bir şekilde ortaya koymuştur.

Sâmirî (السامرى) kelimesinin özel isim olmadığ1; başında elif-lâm takısı ve sonunda nispet yầ'sı olması sebebiyle bir kabileye, bir beldeye ya da bir meslek grubuna mensubiyeti ifade ettiği söylenmektedir. ${ }^{2}$ Kur'ân'a ve Tevrât'a göre Hz.Mûsâ'nın kırk geceliğine Sina Dağı'na çıkması, Sâmirî’nin altın buzağıyı yapıp İsrâiloğullarının ona tapması ve sonrasındaki süreçte yaşananlar ile Tevrât'ın müfessirlere etkileri bu makalenin konusunu oluşturmaktadır. Hz. Mûsâ’nın bulunmadığ1 bu süreçte Sâmirî’nin yaptığı buză̆gya İsrâiloğullarının tapmaya başlaması müfessirlerin ilgisini çekmiştir. Kıssayı ele alırlarken kırk günlük süreçte yaşananlarla ilgili onların bazen Kur'ân'la çelişen ifadeler kullanmış olması, bunun kaynağını araştırma gereği doğurmuş ve bu çalışma yapılmıştir.

Kıssa, İsrâiloğullarıyla ilgili olduğu için müfessirler de İsrâiliyyât’tan yararlanarak açılamalar yapmışlardır. İbranice asıllı olan ve “Allah’la güreşen” anlamındaki İsrâil kelimesinden türeyen İsrâiliyyât, ${ }^{3}$ İsrâilî kaynaktan rivâyet edilen kıssa veya hâdiseye denilmektedir. ${ }^{4}$ İslâm'a ve özellikle tefsire girmiş olan Yahudi, Hıristiyan, eski Fars ve Yakın Doğu kültür havzalanına ve diğer dinlere ait kültür kalıntılarıyla ilgili Hz. Peygamber'e, sahabeye ve müteakip nesillere izafe edilen her türlü haber, İsrâiliyyât kelimesinin manası içine girmektedir. ${ }^{5}$ Müslümanlar, Kur'ân'ın veciz ve özlü oluşundan dolayı, onun açıklanmasında diğer dinlerin tafsilatlı haberlerine başvurmuşlar; çoğun-

1 Çıkış 16: 1-36; Çıkış 17: 1-14; Çı1kış: Çıkış 32/1-35; el-Bakara 2/49-74; el-A'râf 7/136-162; et-Tâhâ 20/77- 97; eşŞuarâ 26/52-67.

2 Ebü'l-Hasen Mukâtil b. Süleymân, Tefsîru Mukâtil b. Süleymân, thk. Abdullah Mahmud Şehâte (Beyrut: Dâru ihyâi't-türâsi'l-Arabî, 1423), 2/65; Ebû Cafer Muhammed b. Cerir et-Taberî, Câmiu'l-beyân an te'vili'l-Kur'ân (Beyrut: Müessesetu'r-risale, 2000), 13/89; 18/363; Ebû Mansûr el-Mâturîdî, Te'vîlâtu ebli's-sünne (Beyrut: Dâru'l-kutubi'lilmiyye, 2005), 7/306; Ebü'l-Hasen Alî b. Muhammed el-Mâverdî, en-Nüket ve'l-uyûn (Beyrut: Dâru'l-kutubi'lilmiyye, ts.), 3/422; Ebü'l-Kâsım Mahmûd b. Ömer ez-Zemahşerî, el-Kesşâf 'an hakẩ iki gavâmidi't-teñîll ve 'uyûni'lekâvîl fî vücûhi't-te vîl (Beyrut: Dâru'l-kutubi'l-Arabî, 1987), 3/81 İbn Atiyye el-Endelüsî, el-Muharrerü'l-vecîz fî̀ tefsîri'l-

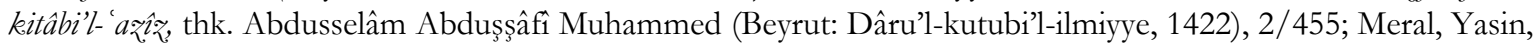
Sâmirînin Buzağısı (Ankara: Ankara Okulu Yayınları, 2018), 110.

3 Mürsel Ethem - Ramazan Ünsal, “Kur'an'ı Anlamada İsrâliyat'in Rolü”, Pamukkale Üniversitesi İlabiyat Fakültesi Dergisi, 7 (2) (Güz/Autumn 2020), 1723.

4 Muhammed Hüseyin ez-Zehebî, et-Tefsîr ve'l-Müfessirûn (Beyrut: Daru ihyâi't-turasi'l-Arabî, 1976), 1/61; İsmail Cerrahoğlu, Tefsir Taribi (Ankara: Diyanet İşleri Başkanlığ1 Yayınları,1988), 1/120; İsmail Cerrahoğlu, Tefsir Usûlï, 10. Bask1 (Ankara: TDV. Yayınları, 1995), 244; Abdullah Aydemir, Tefsirde İsrailiyat (İstanbul: Beyan Yayınları, 2000), 29.

5 Aydemir, Tefsirde Issrailiyat, 29; Enes Büyük, “Tefsirde İsrâiliyyât'ın Arap Kültürüyle İlişkisi Üzerine Bir Araştırma”, Dinbilimleri Akademike Araştırma Dergisi, XIV (2014), 94; Ethem - Ünsal, "Kur'an'1 Anlamada İsrâliyat'ın Rolü”, 1723-1729. 
lukla Abdullah b. Selâm (ö. 43/663), Ka’bu’l-Ahbâr (ö. 32/652-653), Vehb b. Münebbih (ö. 114/732) ve Abdülmelik b. Cüreyc’ten (ö. 150/767) bilgi almış ve aktarmışlardır. ${ }^{6}$

\section{Tevrât'ta Sâmirî Kıssası}

Kitab-1 Mukaddes'te peygamberlerle ve özellikle Hz. Mûsâ’yla ilgili bilgiler bulunmaktadır. Sâmirî kıssası da Tevrât'ta Çıkış 19, 24 ve 32, Yasa'nın Tekrarı (Tesniye) ile Nehemya 9. bölümlerinde geçmektedir. İsrâiloğullarının Kızıldeniz’i geçişlerinden sonra gerçekleştiği belirtilen kıssanın tarihi seyrini şöyle özetlemek mümkündür:

“Rab, Mûsâ'ya Hârûn, Nadav, Avihu ve İsrail'in ileri gelenlerinden 70 kişiyle kendisine gitmelerini ister. Sonra da ona: "Sen bana yalnız yaklaşacaksın." der. ${ }^{7}$ Mûsâ halkı toplayıp Rabbin buyruklarını anlatır. Herkes bir ağızdan, "Rabbin her söylediğini yapacağız." diye karşılık verir. Mûsâ sabah erkenden kalkıp dağın eteğinde bir sunak kurar. İsrail'in on iki oymağını simgeleyen on iki taş sütun diker... Mûsâ antlaşma kitabını halka okur. Halk, tekrar Rabbin söylediğini yapacaklarına söz verir. ${ }^{8}$

Sonra Mûsâ, Hârûn, Nadav, Avihu ve seçilen 70 kişi dağa çıkarlar. İsrail'in Tanrısı'nı görürler. " "Rab Mûsâ'ya, "Dağa, yanıma gel." "Burada bekle, halkın öğrenmesi için üzerine yasalarla buyrukları yazdığım taş levhaları sana vereceğim.”10 der. Hz. Mûsâ, yardımcısı Yeşu’yla hazırlanır. Tanrı Dağı'na çıkarken, İsrail ileri gelenlerine: “Geri dönünceye kadar bizi burada bekleyin. Hârûn'la Hur aranızda; kimin sorunu olursa onlara başvursun." "11 der. Mûsâ dağa çıkınca, bulut dağ1 kaplar. Rabbin görkemi Sina Dağı'nın üzerine iner ve bulut dağı altı gün örter. Yedinci gün Rab bulutun içinden Mûsâ'ya seslenir. Mûsâ bulutun içinden dağa çıkar ve kırk gün kırk gece dağda kalır. ${ }^{12}$

Yasa'nın Tekrarı 9. bölümde Hz. Mûsâ'nın dilinden Tûr'da yaşananlar şöyle anlatılır: “Daha önce taş levhaları almak için dağa çıkmıştım; orada kırk gün, kırk gece kaldım. Ne yedim, ne içtim. Rab Tanrı parmağıyla yazmış olduğu iki taş levhayı bana verdi. Bu levhalar, dağda toplandığınız gün Rabbin ateşin içinden size bildirdiği bütün buyrukları içermekteydi. Kırk gün, kırk gece sonra Rab bana iki taş levhayı, antlaşma levhalarını verdi. 'Haydi, buradan hemen in!' 'Çünkü M1-

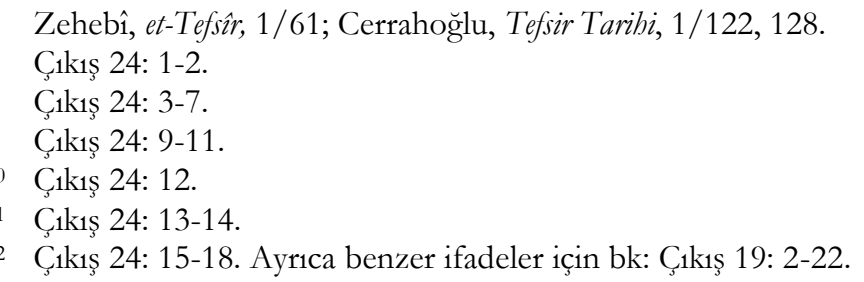


sır'dan çıkardığın halkın yoldan çıktı. Onlar buyurduğum yoldan hemen saptılar."13 "Kendilerine dökme bir put yaptılar.' dedi." ${ }^{14}$

Tevrât, İsrâiloğullarının puta tapma sürecini ve Hz. Mûsâ dağda iken olanları şöyle anlatmaktadır: "Halk Mûsâ'nın gecikip dağdan inmediğini görünce, Hârûn'un çevresine toplandı. Ona, "Kalk, bize öncülük edecek bir ilâh yap. Bizi Mısır'dan çıkaran adama, Mûsâ'ya ne oldu bilmiyoruz!" dedi. Hârûn: "Karılarınızın, oğullarınızın, kızlarınızın kulağındaki altın küpeleri çıkarıp bana getirin." dedi. Herkes kulağındaki küpeyi çıkarıp Hârûn'a getirdi. Hârûn altınları topladı, oymacı aletiyle buzağı biçiminde dökme bir put yaptı. Halk, "Ey İsrâilliler, sizi Mısır'dan çıkaran tanınız budur!" dedi. Hârûn bunu görünce, buzağının önünde bir sunak yaptı ve: "Yarın Rabbin onuruna bayram olacak." diye ilan etti. Ertesi gün halk erkenden kalkıp yakmalık sunular sundu, esenlik sunuları getirdi. Yiyip içmeye oturdu, sonra kalkıp çılgınca eğlendi."15

Mûsâ’nın dağdan inmesi ise şöyle anlatılmaktadır: "Rab Mûsâ'ya, "Aşağı in" dedi, "M1sır'dan çıkardığın halkın baştan çıktı... "Şimdi bana engel olma, bırak öfkem alevlensin, onları yok edeyim. Sonra seni büyük bir ulus yapacağım." Mûsâ Rab'be yalvardı: "Ya Rab, niçin kendi halkına karşı öfken alevlensin? Onları Mısır'dan büyük kudretinle, güçlü elinle çıkardın. Neden Mısırlılar, 'Tanrı kötü amaçla, dağlarda öldürmek, yeryüzünden silmek için onları Mısır'dan çıkardı' desinler? Öfkelenme, halkına yapacağın kötülükten vazgeç. Kulların İbrahim'i, İshak'1, İsrail'i anımsa. Onlara kendi üzerine ant içtin, 'Soyunuzu gökteki yıldızlar kadar çoğaltacağım. Söz verdiğim bu ülkenin tümünü soyunuza vereceğim. Sonsuza dek onlara miras olacak' dedin." Böylece Rab, halkına yapacağını söylediği kötülükten vazgeçti. ${ }^{16}$

"Mûsâ, elinde antlaşma koşulları yazılı iki taş levhayla dağdan indi. Levhaların ön ve arka iki yüzü de yazılıydı. Yeşu, bağrışan halkın sesini duyunca, Mûsâ'ya: "Ordugâhtan savaş sesi geliyor!" dedi. Mûsâ şöyle yanıtladı: "Ne yenenlerin, ne de yenilenlerin sesidir bu. Ezgiler duyuyorum ben. Mûsâ ordugâha yaklaşınca, buzağıyı ve oynayan insanları gördü; çok öfkelendi. Elindeki taş levhaları firlatıp dağın eteğinde parçaladı. Yaptıkları buzağıyı alıp yaktı, toz haline gelinceye dek ezdi, sonra suya serperek İsrâilliler'e içirdi."17 "Hârûn'a: "Bu halk sana ne yaptı ki, onları bu korkunç günaha sürükledin?" dedi. Hârûn: "Öfkelenme, efendim!" diye karşllı verdi, "Bilirsin, halk kötülüğe eğilimlidir. Bana: 'Bize öncülük edecek bir ilah yap. Bizi Mısır'dan çıkaran adama,

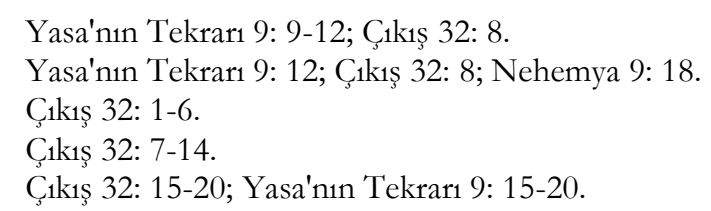


Mûsâ'ya ne oldu bilmiyoruz' dediler. Ben de, 'Kimde altın varsa çıkarsın' dedim. Altınlarını bana verdiler. Ateşe atınca, bu buzağı ortaya çıtı!"18

"Mûsâ halkın başıboş hale geldiğini gördü. Çünkü Hârûn onları dizginlememiş, düşmanlarına alay konusu olmalarına neden olmuştu. Mûsâ ordugâhın girişinde durdu. "Rab'den yana olanlar yanıma gelsin!" dedi. Bütün Levililer çevresine toplandı. Mûsâ şöyle dedi: "İsrail'in Tanrısı Rab diyor ki, 'Herkes kılıcını kuşansın. Ordugâhta kapı kapı dolaşarak kardeşini, komşusunu, yakınını öldürsün.” Levililer Mûsâ'nın buyruğunu yerine getirdiler. O gün halktan 3 bine yakın adam öldürüldü. Mûsâ: "Bugün kendinizi Rab'be adamış oldunuz" dedi. "Herkes öz oğluna, öz kardeşine düşman kesildiği için bugün Rab sizi kutsadı."19

"Mûsâ ertesi gün halka: "Korkunç bir günah işlediniz. Şimdi Rabbin huzuruna çıkacağım. Belki günahınızı bağışlatabilirim." dedi. Sonra Rab'be dönerek: "Çok yazık, bu halk korkunç bir günah işledi." dedi. "Kendilerine altın put yaptılar. Lütfen günahlarını bağışla, yoksa yazdığın kitaptan adımı sil." Rab: "Kim bana karşı günah işlediyse onun adını sileceğim." diye karşlık verdi. "Şimdi git, halkı sana söylediğim yere götür. Meleğim sana öncülük edecek. Ama zamanı gelince günahlarından ötürü onları cezalandıracağım." Rab halkı cezalandırdı."20

Buzağıya tapan İsrâiloğulları, pişman oldukları ve tevbe etmek istedikleri için Mûsâ'dan (as) çözüm isterler. O da Tûr'a tekrar çıkar. Tevrât'ta olay şöyle anlatıllır: "Bir kez daha Rabbin huzurunda bir şey yemeden, içmeden 40 gün 40 gece yere kapanıp kaldım. Çünkü günah işlemiştiniz; Rabbin gözünde kötü olanı yaparak O'nu öfkelendirmiştiniz. Rabbin kızgın öfkesi karşısında korktum. Öfkesi sizi yok edecek kadar alevlenmişti. Ama Rab yakarışımı yine duydu. Rab Hârûn'a da onu yok edecek kadar öfkelenmişti. O sırada Hârûn için de yakardım.”21

Kıssayla ilgili Tevrât’ta, Hz. Mûsâ’nın dağa çıkış öncesi, çıkışı, Allah ile konuşması, levhaları alıp dağdan inmesi, İsrâiloğullarını cezalandırması ve tevbe etmek için tekrar dağa gidişi ayrıntılı anlatılmaktadır. İsrâiloğullarının tevhitten sapmalarının Allah’ta ve Hz. Mâsâ’da oluşturduğu hayal kırıklı̆̆ ile öfkeye vurgu yapılmaktadır.

\section{Kur’ân-1 Kerim'de Sâmirî Kıssası}

Kıssa Kur'ân'da, Tâhâ, A ‘râf, Bakara ve Nisâ sûrelerinde geçmektedir. Kur'ân'daki bilgileri şöyle özetlemek mümkündür:

Ç1kış 32: 21-24.

Çıkış 32: 25-29.

Ç1kıș 32: 30-35.

21 Yasa'nın Tekrarı 9: 18-20. 
İsrâiloğulları Kızıldeniz’i geçtikten sonra yolculuklarına devam etmişlerdi. Yolda puta tapan bir millete rastlamışlar, Allah tarafindan Mûsầya (as) birçok mucize verilmesine ve denizden yine bir mucizeyle kurtulmalarına rağmen puta tapan bu halka imrenmişler ve Mûsâ’dan benzerini yapmasını istemişlerdi. ${ }^{22} \mathrm{Bu}$ ahmaklıkları üzerine şaşkınlık yaşayan Hz. Mûsâ: “...Sizi âlemlere üstün kılmış olan Allah'tan başka bir tanrı mı arayacağım?"23 diyerek onları ikna etmeye çalışmıştı. İsrâiloğulları, Hz. Mûsâ sayesinde, kendilerine işkencelerin en kötüsünü yapan Firavun'dan ${ }^{24}$ kurtuldukları için susmuşlar lakin ikna olmamış, gönüllerindeki tutkudan vazgeçmemişlerdi.

Yola devam ederek kendilerine Allah tarafından va'd edilen Tûr'un sağ yanına yerleşmişlerdi. ${ }^{25}$ Bu esnada Yüce Allah, Mûsâyy (as) Tûr-i Sina'ya davet etmişti. ${ }^{26}$ Önce mîkât için 30 gece süre belirlemiş, arkasından 10 gece daha ekleyerek vakti 40 geceye tamamlamışt. ${ }^{27}$ Bunun üzerine Hz. Mûsâ, İsrâiloğullarının başına kardeşi Hz. Hârûn'u vekil tayin etmiş ${ }^{28}$ ve kendisine itaat edeceğine ve İsrâiloğullarını gözeteceğine, ${ }^{29}$ İsâiloğullarından da kendisine iyi halefler olacaklarına ve Hz. Hârûn'a itaat edeceklerine dair söz almıştı. ${ }^{30}$

Hz. Mûsâ işini sağlama aldıktan ve sözleşmelerini yaptıktan sonra çabucak yola koyulmuştu. Yüce Allah'la Tuva Vadisi'ndeki konuşmasından ${ }^{31}$ ylllarca sonra gelen bu davetin coşkusuyla hızlı hareket etmişti. Randevu yerine Allah'ın tayin ettiği vakitten erken varmıştı. Allah'ın, "Ona Tûr'un sağ yanından seslenmiş ve konuşmak için onu yaklaştırmışık.”32 buyurduğu konuşma gerçekleşmişti.

Allah, Mûsâ’yla (as) konuşmasının hemen başında ona acele etmesinin sebebini sormuştu. ${ }^{33} \mathrm{O}$ da bu soru karşısında, erken ayrılmakla sorumluluğunu eksik yaptığının ve lidersiz kalan kavminin yanlışa düştüğünün ima edildiğini düşünerek garanti verircesine: "Onlar izimdeler.”34

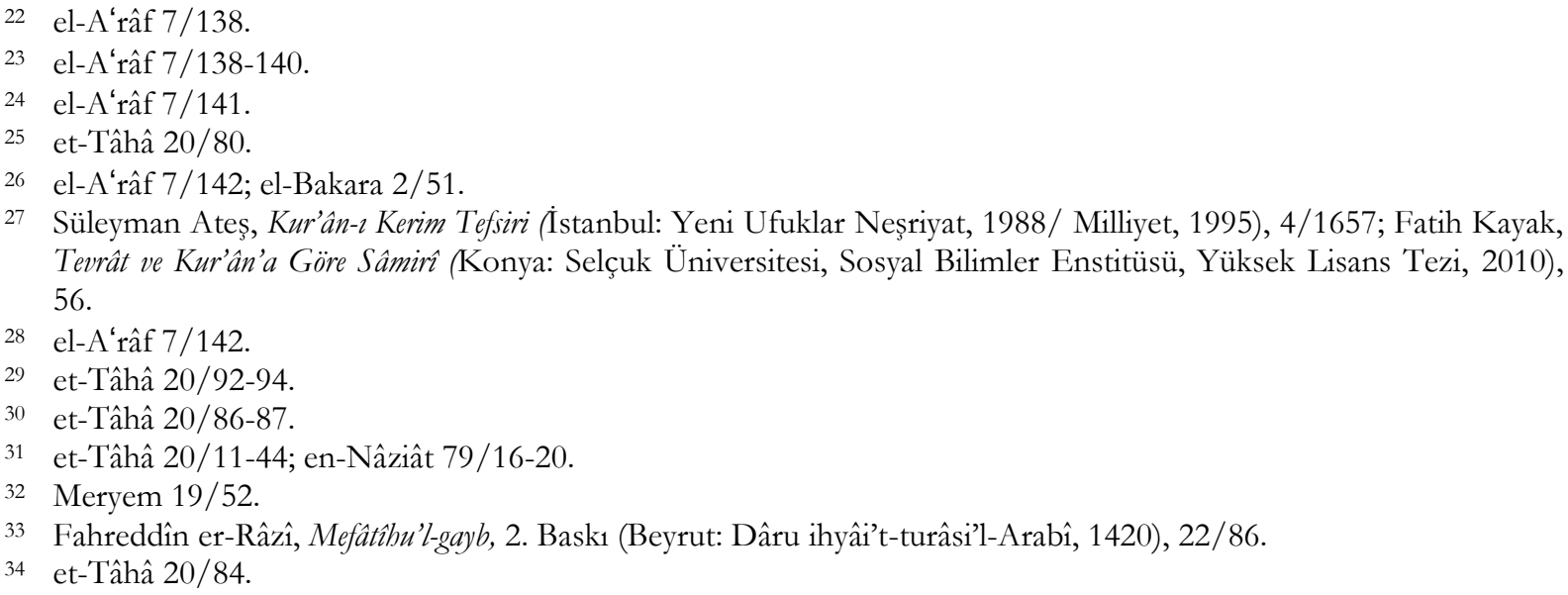


demişti. Fakat Allah, Sâmirî’nin yaptığı putla kavminin saptığını ona haber verince derin bir üzüntü yaşamıştı. ${ }^{35}$

Sâmirî, maharetli bir sanatkârdı. İsrâiloğulları Mısırdan çıkarken Kıptilerin kendilerine emanet ettikleri ziynet eşyalarını beraberlerinde götürmüşlerdi. Bunların günahından kurtulmak için eritmeye karar verip ateşe atmışlardı. Siyak ve sibaktan anlaşıldığı kadarıyla altınları eriten Sâmirî, kendi mücevheratını da içlerine atıvermişti. Daha sonra "er-Rasûl'un" ayak izinden aldığ1 toprağ1 mücevherle karıştırıp böğüren bir buzağı heykeline dönüştürmüştü. Sonra da ona kutsiyet atfederek: "Bu sizin de Mûsâ'nın da tanrısıdır."36 diyerek halkı ona tapmaya çağırmıştı. Sâmirî sapmış ve İsrâiloğullarını da saptırmıştı. ${ }^{37}$

Onun bu buzağı heykeli İsrâiloğullarına, Mısır'dan çıktıktan sonra karşılaştıkları putperest kavmin taptığı ve Mûsâ'dan (as) benzerini istedikleri ilâhtan daha çekici gelmişti. Esaretten özgürlüğe geçişte bir kaç defa zikzaklı davranışlar sergileyerek peygamberi üzen İsrâiloğulları, Hz. Mûsâ’nın yokluğunda kırk gün bile sabredemeyerek heykelden bir tanrıya tapma fikrine tutku düzeyinde saplanmışlardı. Hz. Hârûn da onlara: "Siz bu buzağı ile sınanıyorsunuz. Sizin gerçek Rabbiniz Rahmân'dır. Bana uyun, emrime itaat edin" demişti." (Fakat kavmi:) "Mûsâ bize dönene kadar buna sarılmaktan vazgeçmeyeceğiz." ${ }^{38}$ demişlerdi. İsrâiloğulları buzağıyı tannı edinince kalplerine onun sevgisi içirilmişti. ${ }^{39}$ Ve bu sevgi, nefislerini esir alacak kadar iliklerine işlemişti.

Hz. Mûsâ, Allah’la görüşme/konuşma iştiyakıyla, ${ }^{40}$ aşkıı çılgına çevirdiği kimseler gibi ${ }^{41}$ Tûr-i Sina'daki randevu yerine olanlardan habersiz varmıştı. Âyetlerde onun geldiği esnadaki hâli “acele” ile ifade edilmektedir. Ancak Yüce Allah'ın ona ilk hitabı onu mahcup etmişti. Âyetler incelendiğinde Hz. Mûsâ'nın daha sonra bunu atlattı̆̆ı görülmektedir. Onun, Yüce Allah’ı görme iştiyakını ifade eden Allah ile konuşması şöyledir: "Mûsâ, tayin ettiğimiz vakitte gelip Rabbi onunla konuşunca: "Rabbim! Bana Kendini göster, Sana bakayım!” demişti. Allah: "Beni göremezsin ama dağa bak, eğer o yerinde kalırsa sen de Beni göreceksin!” buyurdu. Rabbi dağa tecelli edince onu yerle bir etti ve Mûsâ da baygın düştü; ayıllnnca: "Ya Rabbi, münezzehsin, Sana tevbe ettim, ben inananların ilkiyim." dedi." ${ }^{42}$

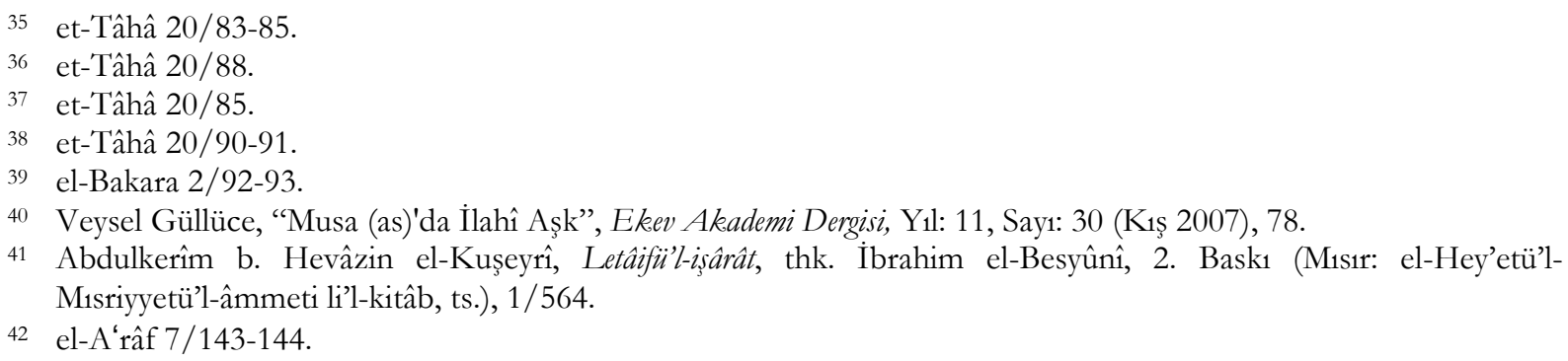


40 günlük mîkâtin bitiminde Yüce Allah, Mûsâ'ya (as) Tevrât'ın levhalarını almasını ve insanları ona uymaya davet etmek üzere İsrâiloğullarına gitmesini emretti. Hz. Mûsâ, Tûr'dan dönerken “öfkeli ve üzgün”dü. ${ }^{43}$ Kavmine varır varmaz azabı hak eden bu eylemleri nedeniyle onları sorgulamaya başladi. İfadeleri şöyleydi: "Benim arkamdan ne kötü olmuşsunuz! Rabbinizin emrinin çabucak gelmesini mi istiyorsunuz?" 44 "Ey milletim! Rabbiniz size güzel bir vaadde bulunmadi mı? Uzun bir zaman mı geçti, yoksa Rabbinizin gazabına mı uğramak istediniz de bana verdiğiniz sözden caydınız?" dedi. Onlar: "Sana verdiğimiz sözden kendiliğimizden caymadık. O milletin ziynet eşyasından bize yükler dolusu taşıtıldı. Biz onları ateşe attık, aynı şekilde Sâmirî de attı." dediler. ${ }^{.45}$ Kavmi sorumluluklarını savuşturacak mazeretler ileri sürerek Sâmirr̂̀yi suçladı.

Hz. Mûsâ onları dinledikten sonra Hârûn’u (as) sorgulamaya, kendi zannınca görevindeki gevşekliğinin cezasını vermeye gitti. Kavmiyle konuşurken sağduyulu davranan Hz. Mûsâ, Hz. Hârûn’u görür görmez, “Tevrât'ın levhalarını attı. Ve: “Onların saptığını gördüğünde benim izimce gelmene ne mani oldu?! Yoksa emrime karşı mı geldin?!” deyip saçından, sakalından tutup çekmeye başladı." ${ }^{46}$ Hârûn: "Ey annemin oğlu! Bu millet beni küçümsedi; az kalsın öldürüyorlardı. Bana, düşmanları sevindirecek şekilde davranma! Beni bu zalim milletle bir tutma!" "47 "İsrâiloğullarının içine ayrılık soktun, sözümü dinlemedin!” diyeceğinden endişe ettim." ${ }^{48}$ diyerek onların isyankârlığını anlatmaya başladı.

Hz. Mûsâ kardeşinin, bu ihanetin parçası olmadığını görünce rahatladı. Öfkesi yatıştı. Sonra: "Rabbim! Beni ve kardeşimi bağışla, bize acı, Sen merhametlilerin merhametlisisin!" dedi." ${ }^{49}$ Levhaları ald1 ${ }^{50}$ Sirada Sâmirî̀yi sorgulamak vardı. Hz. Mûsâ ona gitti ve: "Sâmirî! Senin derdin nedir?” dedi. (Sâmirî) "Ben, onların görmedikleri bir şeyi gördüm. O resulün izinden bir avuç toprak alıp onu potanın içine attım. İşte böylece nefsim böyle yapmayı bana hoş gösterdi.” dedi. (Hz. Mûsâ Sâmirî̀yi sorguladıktan sonra): “Defol!” Artık ömür boyunca: “Dokunmak yok, benden uzak durun!" diyeceksin, yalnız yaşamaya mahkûm olacaksın. Ayrıca senin asla kurtulamayacağın bir ceza günün var. Şimdi tapınıp durduğun tanrına bak! Biz onu yakacağız, sonra da kül

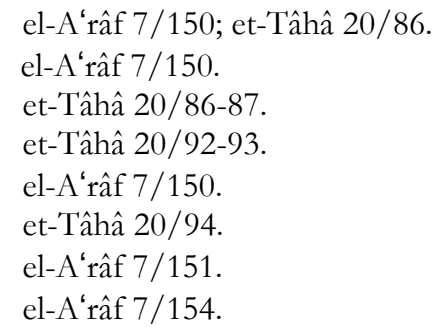


haline getirip denize savuracağız." ${ }^{51}$ diyerek ilâhî cezaya uğrayacağını söyleyip onu kovdu. Böylece İsrâiloğulları onun sihirli sanatından ve zehirli dilinden korunmuş oldu.

Burada dikkatleri çeken husus Sâmirî̀nin, irtidat etmesine ve İsrâiloğullarını saptırmasına rağmen onun infaz edilmeyip sürgüne gönderilmiş olmasıdır. Zira kendisinin itirafı ve şahitlerin şahitliğiyle suçu sabitti. Allah, Sâmirî̀ye verilen bu cezayı onayladığını şöyle bildirmektedir: "Buzağıyı tanrı olarak benimseyenler Rablerinin öfkesine ve dünya hayatında alçaklığa uğrayacaklardır; iftira edenleri böylece cezalandırırız. Kötülük işleyip ardından tevbe edenler ve inananlar bilsinler ki Rabbin, bu hareketlerinin ardından onları şüphesiz bağışlar ve merhamet eder." ${ }^{52}$

İsrâiloğulları, Hz. Mûsâ’nın Tevrât levhalarıyla döndüğ̈nü görünce aldandıklarını anlamışlardı. Ayrıca onun mantık dolusu soruları ve azarıyla karşılaşınca pişmanlık da yaşamaya başlamışlardı. Bu durumu âyetler şöyle tarif etmektedir: "Elleri böğründe, çaresiz kalıp sapıtmış olduklarını görünce: "Ĕ̆er Rabbimiz bize acımaz ve bizi bağışlamazsa, and olsun ki mahvoluruz!" dediler." 53 Pişmanlıklarını arz ettikten sonra ilâhi bir cezaya uğrama endişesine kapıldılar.

İsrâiloğulları hatalarını anladıktan sonra Hz. Mûsâ onların Allah'tan af dilemeleri gerektiğini ifade ederek şöyle demişti: “... Ey milletim! Buzağıyı tanrı olarak benimsemekle kendinize yazık ettiniz. Yaratanınıza tevbe edin ve nefislerinizi öldürün. Bu, Yaratanınız katında sizin için hayırlı olur; O daima tevbeleri kabul edendir ve merhamet sahibi olduğu için tevbenizi kabul eder." demişti." ${ }^{54}$

Bu bir çıkış kapısıydı. Allah'ın merhameti ve bağışlamadaki cömertliği onlara müjde gibi gelmişti. Kavmi bunu kabul etmişti. Bunun üzerine Yüce Allah, Mûsâ’ya (as) İsrâiloğullarından 70 kişiyi seçip Tûr-i Sina’ya getirmesini, orada halkı adına hep birlikte tevbe etmelerini emir buyurmuştu. Allah böylece onları cezalandırmamıştı. Nitekim "Sonra bunun ardından, şükredersiniz diye, sizi bağışlamıştık." ${ }^{55}$ diyerek bu sınırsız affını haber vermiştir.

Hz. Mûsâ içlerinden toplumda saygınlığı olan 70 kişiyi seçmişti. ${ }^{56}$ Tûr-i Sina’ya varmışlardı. İşte orada İsrâiloğullarını bir azgınlık tutmuştu. Onlar, Mûsâ'nın (as) ilâhının Sâmirî'nin buzağı heykeli gibi bir şey olduğunu sanmışlardı. Gözlerinin önünde duran bir şey olmasını arzulamışlard1. Onlar, 'Allah, Mûsâ'yı kırk geceliğine buraya davet ettiğine; Tevrât'ın levhalarını ona burada

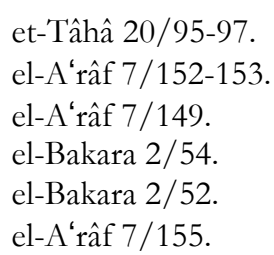


verdiğine; tevbe etmek için bizi de buraya çağırdığına göre Allah buradadır. Buzağıyı gördügümüz gibi Allah’1 da görmeliyiz. Eğer bize görünmüyorsa Mûsâ bizi kandırıyor.' düşüncesindeydiler. Bunun için hadlerini aşmış, azgınlaşmaya başlamışlardı. Kur'ân olanları şöyle haber vermektedir: “Ey Mûsâ! Allah'ı apaçık görmedikçe sana inanmayacağız" demiştiniz de gözleriniz göre göre sizi yıldırım çarpmıştı." 57 "Onları sarsıntı tutunca (Mûsâ) dedi ki: "Rabbim! Dileseydin daha önce beni ve onları yok ederdin, aramızdaki beyinsizlerin yaptıklarından ötürü bizi helâk eder misin? Bu, Senin imtihanından başka bir şey değildir..." ${ }^{58} \mathrm{~Hz}$. Mûsâ, Allah’a yakarmaya başlayınca Rabbi onu kırmadı. "Ölümünüzden sonra, şükredesiniz diye sizi tekrar diriltmiştik." gibi İsrâiloğullarını diriltti.

Kıssayla ilgili Tevrât'ın ve Kur'ân'ın verdiği bilgilerin büyük kısmında benzerlik vardır. Bunların müfessirleri çok fazla meşgul etmediği görülmektedir. Ancak kıssayla ilgili önemli farklılıklar da bulunmaktadır. Tevrât'ta, Kur'ân'ın Ulûhiyet anlayışına, Hz. Hârûn'un peygamberlik vakarına ve vakıanın seyrine uymayan bilgiler; Kur'ân'da ise müphem kalan noktalar ile birden çok manaya gelebilen kavramlar bulunmaktadır. Müfessirler işte bu hususları tahlil etmeye çalışmış ve bazı tutarsızlıklar sergilemişlerdir.

\section{Tevrât ile Kur’ân'da Sâmirî Kıssasının Benzerlikleri}

Kıssasının Tevrât ile Kur'ân arasında küçük farklılıklar barındıran benzerliklerini şöyle s1ralamak mümkündür:

a) Hz. Mûsâ'nın dağa iki sefer çıktığı ortak noktalardan biridir. Hem Kur'ân'da hem de Tevrât'ta birinci gidişin Tevrât'1 almak, ikincisinin tevbe edip bağışlanma dilemek için olduğu belirtilmektedir. Ancak Kur'ân'da, Hz. Mûsâ'nın dağda sadece birinci gidişte 40 gece kaldığı; Tevrât'ta ise hem ilk gidişte hem de tevbe için ikinci gidişte 40 gün 40 gece kaldığ ifade edilmektedir.

b) Kur'ân'da Hz. Mûsâ’nın ilk seferde dağa yalnız gittiği; Tevrât'ta ise Tevrât'ı almak üzere 70 kişiyle dağa gittiği ancak dağın zirvesine tek başına varmasının emredildiği yazılmaktadır.

c) Allah'ın, Hz. Mûsâ'ya İsrâiloğullarının buzağıya tapmaya başladıklanını haber verdiği iki kitapta da geçmektedir. Ancak Kur'ân'da hangi zaman aralığında olduğu belirtilmemektedir.

el-Bakara 2/55; en-Nisâ, 4/153.

el-A'râf $7 / 155$.

el-Bakara 2/56. 
Tevrât'ta ise 40 gecenin bitiminde, levhalar verildikten sonra Hz. Mûsâ'nın durumdan haberdar edildiği bildirilmektedir. ${ }^{60}$

d) Her iki kitapta da Hz. Mûsâ’nın gecikmesinin bahane edildiği anlatılmaktadır. ${ }^{61}$ Kur'ân'ın anlatımı şu ayrıntıyı vermektedir: "Mûsâ'ya otuz gece vade verip sonra buna on gece daha ekledik; böylece Rabbinin tayin ettiği müddet 40 geceye tamamlandı." ${ }^{\prime 2}$ Bu ifadeden $\mathrm{Hz}$. Mûsâ’nın Tûr'a ilk davet edildiğinde belirlenen sürenin 30 gece olduğu anlaşılmaktadır. O, İsrâiloğullarıyla vedalaştığında 30 geceliğine gitmişti. Vakit tamamlanıp Hz. Mûsâ dönmeyince Sâmirî’nin onları buzağıya tapmaya çağırdığı ve gerekçe olarak da gecikmesinden yararlanarak “o unuttu" ${ }^{63}$ dediği görülmektedir. Hz. Mûsâ'nın onları sorgularken, "uzun bir zaman m1 geçti?”, deyişinden bu birkaç günlük gecikmeyi kastetmiş olması muhtemeldir.

e) Hem Kur'ân'da hem de Tevrât'ta Hz. Mûsâ'nın Allah'tan af dilediği ve tövbe etmek için Tûr’a ikinci defa gittiği yazılmaktadır. Kur'ân'da Hz. Mûsâ’nın ikinci gidişinde ona İsrâiloğullarından 70 kişinin eşlik ettiğij; onların Tûr'a vardıktan sonra azgınlaşarak Mûsâ'dan (as) Allah'ı kendilerine açıkça göstermesini istedikleri ve bunun üzerine cezalandırıldıklarr ${ }^{65}$ anlatılırken Tevrât’ta Hz. Mûsâ'nın ikinci gidişte yalnız olduğu anlaşılmaktadır. ${ }^{66}$

\section{Kıssanın Tevrât ile Kur’ân'daki Farklılıkları ve Bunların Müfessirlerin Yorumla- rına Etkileri}

Kıssayla ilgili Tevrât'ta bulunan ancak Kur'ân'da detay verilmeyen bazı bilgiler vardır. Bunların bir kısmı Kur'ân'la uyumluyken, bazıları tezat arz etmektedir. İşte bu bilgiler ile Tevrât'nn dışındaki diğer bazı İsrâiliyyât kaynaklarının naklettikleri müfessirleri çelişkiye düşürmüştür. ${ }^{67} \mathrm{Bu}$ farklılıkları ve müfessirlere etkilerini şöyle sıralamak mümkündür:

a) Tevrât'ta Hz. Mûsâ'nın dağa ilk çıktığında bir bulutun dağ1 kapladığı, Hz. Mûsâ'nın 7. günde bulutun içinden geçerek dağa çıtı̆̆ğ zikredilmektedir. ${ }^{68}$ Ancak Kur'ân bu hususta herhangi bir bilgi vermemektedir.

60 Bk: Yasa'nın Tekrarı 9: 11; Çıkış 32: 7-8.

61 el-A'râf 7/142; Çıkış 32: 1.

62 el-A'râf $7 / 142$.

63 et-Tâhâ $20 / 88$.

64 et-Tâhâ $20 / 86$.

65 Bk: el-Bakara 2/55; en-Nisâ 4/153; el-A'râf 7/155.

66 Bk: Yasa'nın Tekrarı 9: 18.

67 Meral, Sâmirìnin Buzağısı, 65-70.

68 Bk: Çıkış 24: 15-18. 
Râzî (ö. 606/1210) ve Ebû Hayyân (ö. 745/1344), Tevrât’a benzer bir şekilde şöyle demektedir: “Bu 70 kişi Tûr’a yaklaştıklarında dağın tepesini bir duman kaplamış, Hz. Mûsâ onlarla dumanın içine girmiş. Secdeye kapanmışlar. Allah'ın, Hz. Mûsâ ile konuşmasını, ona emir ve yasaklarda bulunmasını duymuşlar. Sonra bulut dağılmış, onlar da Hz. Mûsâ’ya dönerek: "Allah’1 açıçça görmedikçe iman etmeyiz." ${ }^{69}$ demeye başlamış." ${ }^{\text {70 }}$ Beydâvî (ö. 685/1286), Nîsâbûrî (ö. 730/1329), Ebüssuûd (ö. 982/1574) ve Ömer Nasuhi Bilmen de aynı görüşleri yazmışlardır. ${ }^{71}$ Müfessirler Tevrât'ın etkisinde kalarak ikinci gidişi birinci gidiş gibi ifade etmişler ve 70 kişi ile dumandan bahsetmişlerdir.

Taberî (ö. 310/923) ile İbn Kesîr (ö. 774/1373) ise İbn İshâk’tan şunu nakletmektedir: “Hz. Mûsâ kavminin yanına dönünce, onların buzağıya taptıklarını gördü. Kardeşine ve Sâmirî'ye söyleyeceklerini söyledi. Ve buzağıyı parçalayarak denize attı. Sonra onların arasından en seçkin 70 kişiyi seçti ve dedi ki: "Haydin Allah'a varın ve işlediklerinizden dolayı tevbe edip kavminizden geride bıraktıklarınız için bağışlanma dileyin, oruç tutun, temizlenin ve elbiselerinizi de arıtın.” diyerek Rabbinin tayin ettiği vakitte mîkât için onları Tûr-i Sina'ya çıardı... 70 kişi Allah ile buluşmaya gittiklerinde dediler ki: "Ey Mûsâ, Rabbinden bizim adımıza dile, Rabbimizin sözünü duymak istiyoruz. Mûsâ peki, olur dedi ve dağa yaklaşınca üzerine bir bulut kümesi geldi ve bütün dağı kapladı. Mûsâ yaklaşarak onun içine girdi ve kavmine de "yaklaşın” dedi. Mûsâ Allah ile konuştuğu sırada parlak bir nûr beliriyordu ki Âdemoğullarının hiç birisi ona bakmaya güç yetiremiyordu. Ona perdenin arkasından bakabiliyorlardı. O seçilenler de ona yaklaştılar ve bulutun içine girince secdeye kapandılar ve Allah'ın Mûsâ ile konuştuğunu dinlediler. Ona, şunu yap, bunu yapma diye emir ve yasaklarını bildiriyordu. Allah'ın emri tamamlanınca Mûsâ'nın üzerindeki bulut açıldı. Mûsâ onlara yaklaştı. Onlar dediler ki: "Biz Allah'ı açıkça görünceye kadar sana inanmayacağız.’72 Bunun üzerine onları sarsıntı kaplayıverdi ve hepsi birden öldü. Mûsâ kalktı, Rabbine yalvard1, dua etti...”73 Tevrât bu hadisenin Tûr’a birinci gidişte gerçekleştiğini yazarken Taberî ve İbn Kesîr’in aktardığı rivâyet buluttan bahsetmekte ancak biraz önce zikredilen müfessirlerden

69 el-Bakara 2/55.

70 Râzî, Mefâtîhu'l-gayb, 15/376; Ebû Hayyân el-Endelûsî, el-Babrï'l-mubît, thk. Sidkî Muhammed Cemil (Beyrut: Dâru'l-Fikr, 1420), 5/187.

71 Nâsırüddîn Ebû Saîd Abdullah b. Ömer el-Beyzâvî, Envâru't-tenzîl ve esrâru't-te'vîl (Beyrut: Dâru'l-kutubi'l-ilmiyye, 1988), 1/362; Nizâmuddîn en-Nîsâbûrî, Garâibü'l-Kur'ân ve regâibü'l-Furkân, thk. eş-Şeyh Zekeriya Umeyrât (Beyrut: Dâru'l-kutubi'l-ilmiyye, 1416), 1/290; Ebüssuûd, İssâdü'l-'akli's-selìm ilâ mezâya'l-Kitâbi'l-Kerîm (Beyrut: Dâru ihyâi't-turâsi'l-Arabî, ts.), 1/103; Ömer Nasuhi Bilmen, Kur'ân-ı Kerim'in Türkse Meâli Alisi ve Tefsiri (İstanbul: Bilmen Yayınevi, ts.), 2/1098.

72 el-Bakara 2/55.

73 Taberî, Câmiu'l-beyân, 2/86-89 13/140-141; Ebü'l-Fida İsmail b. Kesîr, Tefsiru'l-Kur'âni'l-ąîm (Beyrut: Dâru'lma'rife, 1988), 1/97; 2/260; Ebü’l-Hasen Alâüddîn Alî b. Muhammed el-Hâzin, Lübâbü't-te'vîl fì me âni't-ten₹îll (Beyrut: Dâru'l-kutubi'l-ilmiyye, 1415), 2/254. 
farklı olarak bunun ikinci gidişte gerçekleştiğini ifade etmektedir. 70 kişinin ikinci gidişte $\mathrm{Hz}$. Mûsâ'yla olduğu görüşü Kur'ân'a uygun düşmektedir.

b) Tevrât'ta bir yerde Hz. Mûsâ'nın dağa tek başına çıkmasının emredildiği yazılırken başka bir yerde onun yardımcısı Yeşu'yla çıktığı söylenmektedir. ${ }^{74}$ Dönüşte de yine Yeşu'nun yanında olduğu ifade edilmektedir. ${ }^{75}$ Kur'ân'da kullanılan bütün lafızların müfred olmasından $\mathrm{Hz}$. Mûsâ’nın giderken de, dönerken de yalnız olduğu anlaşılmaktadır. İbn Âşûr (ö. 1973), Tevrât’a uygun bir yorumla Hz. Mûsâ'nın Tûr’a ilk seferinde Yûşa ile gittiğini söylemektedir. ${ }^{76}$

c) Tevrât'ta birinci gidişte hem Hz. Mûsâ'nın hem de seçilmiş 70 kişinin Allah’ı gördüklerinden ve herhangi bir sıkıntı yaşamadıklarından bahsedilmektedir. ${ }^{77}$ Kur'ân'da birinci gidişte Hz. Mûsâ’nın yalnız olduğu ve Allah’ı görmek istediği; Allah'ın dağa tecellisi karşısında baygınlık geçirdiği yazılmaktadır. ${ }^{78}$ Seçilmiş 70 kişinin ikinci gidişte Mûsâ’yla (as) oldukları ve o zaman Allah’1 görmekte 1srar ettikleri, ancak bunun sonucunda cezalandırıldıkları ifade edilmektedir. ${ }^{79}$

Bu farklılık, müfessirleri çelişkiye düşüren bir husus olmuştur. Yüce Allah'ın, “ “

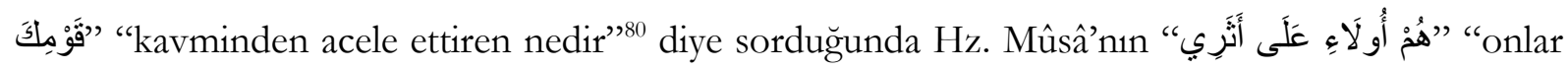
izimdeler” cevabını vermiş olması, müfessirlerin büyük çoğunluğunu Kur'ân'la örtüşmeyen tutumlar takınmaya ve bunun sonucunda da âyeti Tevrât'in ifadesi doğrultusunda tefsir etmeye yöneltmiştir. Âyetlerin siyak ve sibakı ile kıssanın diğer sûrelerde geçen ifadelerine bakıldığında bu konuşmanın birinci gidişte gerçekleştiği ve Hz. Mûsâ’nın yalnız olduğu kesin olarak anlaşılmaktadır. Ancak buna rağmen müfessirlerin çoğunluğu bu âyette bahsedilen ilk buluşmaya onun 70 kişiyle veya bir grupla gittiği görüşündedir.

Bu âyetlerde geçen iki husus tartışmanın odağını oluşturmuştur. Birincisi, “ "مَا أَعْجَلَكَ عَنْ

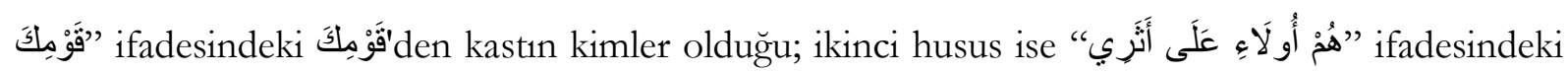
عَلَى أَثَرِّري

1) فَوْْهِكَ İfadesi:

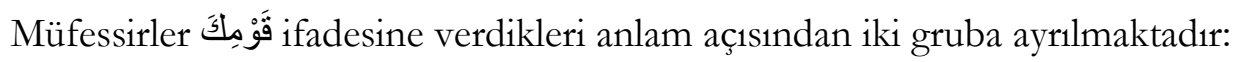

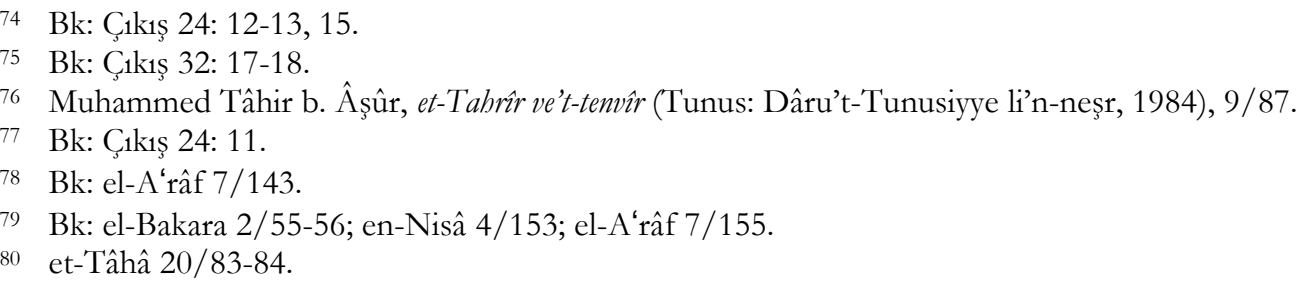


I- Büyük çoğunluk "kavim” ile kastedilenin İsrâiloğullarından bir grup veya seçilen 70 kişi olduğu görüşündedir. Mâturîdî (ö. 333/944), “Hz. Mûsâ Tevrât’ı almak için kavminden bir grupla dağa gittiğinde acele etti ve beraberindekiler geride kaldı. Yüce Allah o zaman ona böyle dedi. O da: "Onlar arkamdan geliyorlar" cevabını verdi." demektedir." "11 Mekkî b. Ebî Tâlib (ö. 437/1045) قيل lafzıyla: “Hz. Mûsâ İsrâiloğullarından seçkin bir grupla Tûr'a varınca, acele edip tek başına va’d edilen yere geldi. Yüce Allah niçin acele edip kavminden önce geldiğini sordu.” demektedir. ${ }^{82}$

Mukâtil b. Süleymân (ö. 150/767), Semerkandî (ö. 373/983), Sa ‘lebî (ö. 427/1035), Vâhidî (ö. 468/1076), Zemahşerî (ö. 538/1144), Begâvî (ö. 516/1122), İbn Cevzî (ö. 597/1201), Hâzin (ö. 741/1341), Nahcuvânî (ö. 920/1514), İbn Acîbe (ö. 1224/1809) ve Alûsî (ö. 1270/1854) ise 'فوَّْلكَ den kastın seçilen 70 kişi olduğu görüşündedir. ${ }^{83}$ Râzî, “onlar”dan kastın, Hz. Mûsâ ile Tûr'a gitmek için seçilen 70 temsilci veya İsrâiloğullarının hepsi olabileceğine dair görüşler aktarmakta; ${ }^{84}$ ayrıca İbn Abbâs'tan (ra) şunu nakletmektedir: "Hz. Mûsâ, beraberinde 70 kişiyle gelir, dağa çıkar. O 70 kişi ise Tûr'un eteklerinde bekler." ${ }^{85}$

Zemahşerî, “Hz. Mûsâ’nın Allah’ı görme talebinin sebebi, kendilerini beyinsiz ve sapkın olarak niteleyip teberri ettiği bu (70 kişilik nakib) kimseleri susturmak, taleplerinin yanlışlığını itiraf ettirmektir. Zira onlar Allah’ı görmeyi talep ettiklerinde Hz. Mûsâ onları yadırgamıs, hatalarını bildirmiş, hakkı kendilerine anlatmış fakat onlar inat etmişler, hatta inatta iyice aşırı giderek "Allah’1 açıkça görmeden sana asla iman etmeyiz.” demişlerdir. Bu yüzden de Hz. Mûsâ onlara bunun imkânsız olduğunu belirten, "Sen beni asla göremezsin." şeklindeki ilâhi fermanı bizzat işiterek emin olmalarını, içlerine düşen şüphenin ortadan kalkmasını istemiştir... Şayet, "Peki, neden Hz. Mûsâ "Ya Rabbi! Onlara kendini göster de Sana baksınlar." dememiş” dersen şöyle derim: Çünkü Allah sadece Hz. Mûsâ ile konuşmakta, onlar ise dinlemektedir." ${ }^{\text {"6 }}$

81 Mâturîdî, Te'vîlât, 7/298-299.

82 Mekkî b. Ebî Tâlib, el-Hidâye ilâ bulüği'n-nihâye fî̀ ilmi meâni'l-Kur'ân ve tefsîribi (Câmiatu'ş-şârika: Külliyetü’ş-şerîa ve dırâsâti’l-İslâmiyye, Mecmâatu buhûsi'l-kitab ve's-sünne, 2008), 7/4679-4681.

83 Mukâtil, Tefsîru Mukâtil, 1/104-105, 3/36; Ebü'l-Leys es-Semerkândî, Babrûl-ulûm (Şâmile), 2/408; Ahmed b. Muhammed b. İbrahim Sa'lebî, el-Kesf ve'l-beyân an tefsiri'l-Kur'ân (Beyrut: Dâru ihyâi't-turâsi'l-Arabî, 2002), 6/256257; Zemahşerî, el-Keşşâf, 3/80; Ebû Muhammed el-Ferrâ el-Begavî, Me âlimü't-tenzîll, thk. Abdurrezâk el-Mehdî, 1. Bask1 (Beyrut: Dâru İhyâi't-turâsi'l-Arabî, 1420), 3/271; Ebü'l-Ferec Cemâlüddîn b. Cevzî, Zâdü'l-mesîr fì 'ilmi'ttefsîr, thk. Abdurrezâk el-Mehdî (Beyrut: Dâru'l-Kitabi'l-Arabî, 1422), 3/171; Hâzin, Lübâb, 3/209; Ni'metullah Nahcuvânî, el-Fevâtibu'l-ilâhiyye ve'l-mefâtibu'l-gaybiyye el-muvaddiba li'l-kelimi'l-Kur'ânîyye ve'l-bikemi'l-furkâniyye (Misir: Dâru rekâbî li'n-neşr, 1999), 1/519; Ahmed İbn Acîbe eş-Şâzelî, el-Bahrü'l-medîd fî tefsîri'l-Ķur'âni'l-mecîd, thk. Ahmed Abdullah el-Kureşî (Kahire: Neşreden: Hasan Abbâs Zekî, 1419), 3/409-410; Şehâbeddîn Mahmûd el-Âlûsî, Rûhu'l-me 'ân̂̀ fì tefsîri'l-Kur'âni'l- 'azî̀m ve's-seb 'i'l-mesânî, thk. Ali Abdulbârî Atiyye (Dâru'l-kutubi'l-ilmiyye, 1415), $8 / 552$.

84 Râzî, Mefâtîhu'l-gayb, 22/86.

85 Râzî̀, Mefâtîhu'l-gayb, 14/358.

86 Zemahșerî, el-Keșsâf, 2/153; 3/81. 
Zemahşerî burada kendi mu’tezili görüşünü desteklemek için Hz. Mûsâ'nın, Allah'ın görülmeyeceğini kesin bildiği için kendi ifadesiyle sorduğunu söylemektedir. Fakat müfessirin buradaki hatası Tevrat'tan etkilenerek bu 70 kişinin Allah'1 duyduğunu belirtmesidir. Oysa Allah'ı duyabilen birilerinin azgınlaşıp tehditler savurarak Allah'1 görmeyi istemeleri düşünülemez. Zira Allah'ın sesini duysalardı belki Hz. Mûsâ gibi yakarışta bulunabilirlerdi, ölüm cezasını hak edecek kadar azgınlaşamazlardı. Ayrıca onların Hz. Mûsâ’nın Allah ile konuşmasını duyduklarına dair Kur'ân'da veya sünnette herhangi bir delil bulunmamaktadır.

Kurtûbî (ö. 671/1273) iki anlam vermektedir. (1) Hz. Mûsâ, İsrâiloğullarının başına Hz. Hârûn'u halef bırakmış, kendisi de 70 kişiyle mîkâta gitmişti. "Kavimden” kastı bütün İsrâiloğullarıdır. "Arkamdan geliyorlar." sözleriyle kavmi için: "Onlar yakınımda bulunuyorlar ve kendilerine dönmemi bekliyorlar." demek istemişti." (2) O, "kavim" ile seçtiği 70 kişiyi kastetmişti. Kurtûbî müfessirlerce yapılmış olan yorumları nakletmiş ve علي اثري‘ye “yolumdalar/izimdeler” dediğini; bununla sîretin takibini, "peşimden geliyorlar" diyerek de fiziksel takibi kast ettiğini belirtmekte-

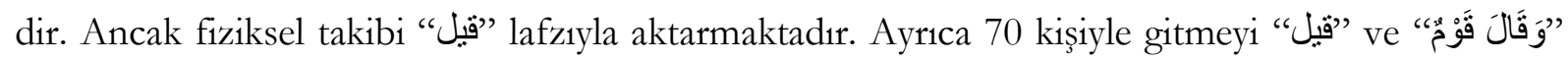
ifadeleriyle nakletmektedir. ${ }^{87}$ Görüldüğü gibi Kurtûbî Kur'ân’a uygun olan dağa “yalnız gitti” görüşünü tercih etmektedir.

Nesefî ise (ö. 710/1310), âyetlerde geçen bu konuşmanın ikinci gidişte gerçekleştiği kanaatindedir. "70 kişi Tûr’a gelince biz diğerleri gibi buzağıya tapmadık, bize Allah’1 açıkça göster." dediklerini belirtir. ${ }^{88}$ Nesefî, el-A'râf 7/155. âyetin tefsirinde: "Mûsâ'nın "buzağıya tapmaktan ötürü tevbe etmek için seçtiği 70 kişidir. Hz. Mûsâ onlarla beraber belirlenen mîkât için Tûr’a gittiğinde Allah'ın kelâmına olan şevkinden öne geçti. Onların kendisini takip ederek arkasından gitmesini emrettiğinde yüce Allah: “Acele ettiren nedir?” dedi... Hz. Mûsâ: "Kavmim arkamdadır." cevabını verdi." demektedir. ${ }^{89}$ Bu yorum da zorlamadır ve Tâhâ $20 / 84$ ve 85 . âyetlerdeki siyak ve sibakla uyuşmamaktadır.

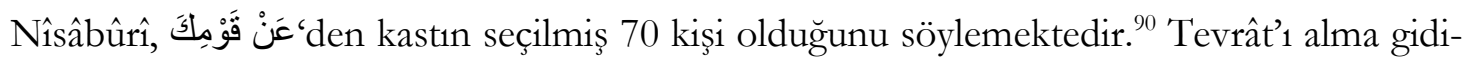
şini kast ederek, "kimi, "Rabbi, Mûsầya (as) İsrâiloğullarından 70 kişiyle Tûr'a gelmesini emretti. Onlar, Allah’ın kelâmını işitince Allah’ı görmek istediler. Ve: “Bize Allah’ı açıkça göstermedikçe

87 Ebû Abdillâh Muhammed b. Ahmed el-Kurtubî, el-Câmi li-abkâmi'l-Kur'ân, thk. Ahmed el-Berdûnî ve İbrahim Atfîş, 2. Bask1 (Kahire: Dâru'l-kutubi'l-Misriyye, 1384/1964), 1/395; 11/232; el-Camiu li abkâmi'l-Kur'ân, trc. M. Beşir Eryarsoy (İstanbul: Buruc Yayınları, 2004), 11/397.

88 Ebü'l-Berekât Abdullah b. Ahmed en-Nesefí, Medâriku't-tenzîl ve hakâiku't-te'vîl (İstanbul: Kahraman Yayınlar1, 1984), $1 / 49$.

89 Nesefî, Medârik, 2/79; 3/61.

90 Nîsâbûrî, Garâibü'l-Kur'ân, 3/326; 4/564. 
sana inanmayı, dediler.” kanaatindedir. İkinci gruptakiler de, 'Buzağıya tapmaktan ötürü nefislerini öldürmeden önce tevbe için gidenlerdir.' görüşündedir." demektedir. ${ }^{91}$ Müfessir önceliği Tevrât çizgisinde tefsir edenlere vermektedir.

Ebüssuûd, Hz. Mûsâ'nın hem Tevrât'ı almak üzere hem de İsrâiloğullarının buzağıya tapmasından sonra 70 kişiyle Tûr’a gittiğini söylemekte ve İbn İshâk'tan nakledilen rivâyeti aktarmaktadır. ${ }^{92}$ Şevkânî (ö. 1250/1834) âyete "Hz. Mûsâ’nın kavminden seçtiği kimselerden ayrilıp erken gitmesi" anlamını vermektedir..$^{33}$ Ömer Nasuhi Bilmen ve Süleyman Ateş, "kavminden" kastın seçilen 70 kişi olduğu görüşündedir. ${ }^{94}$

II- Baz1 müfessirler عَنْ فَوْهِكَ dan kastın bütün İsrâiloğulları olduğu kanaatindedir. Onlara göre Hz. Mûsâ: "Kavmim arkamdan gelmektedir. Aramızda fazla mesafe bulunmamaktadır.” demek istemiştir. Bu konuda bazı rivâyetler de nakledilmiştir. Taberî, İbn İshâk'tan şunu aktarmaktadır: “Hz. Mûsâ, Hz. Hârûn'un İsrâiloğullarıyla beraber kendisini takip etmesini ve kendisine yetişmesini istedi." "Allah: "Niçin onlardan önce geldin ve onları geride bıraktın, onlarla olmadın?” buyurduğunda Hz. Mûsâ: 'Kavmim arkamdan geliyor, bana yetişecek.' cevabını verdi.” Sonra da İbn İshâk'1n: “Hz. Hârûn’un da Sâmirî ve İsrâiloğullanyla onun peşinden giderek ona kavuşmaya çalıştı." dediğini nakletmektedir. ${ }^{95}$

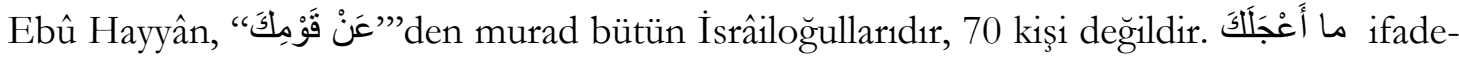
sinden Hz. Mûsâ'nın acele etmesi değil, İsrâiloğullarının gecikmesi kast edilmiştir. Zira bu manayı da içermektedir." "Bu konuşma Hz. Mûsâ’nın Tûr'a gelişinin başında gerçekleşti." demektedir. ${ }^{96}$

İbn Âşûr, “عَّلي اثري"den kastın İsrâiloğullarının arkasında yürümekte olduğunu ve onun münâcât için öne geçip gittiğini ifade etmektedir. ${ }^{97}$ İbn Âşûr başka bir yerde, "Allah, Mûsâ’ya (as) kırk günlük münâcât için Tûr’a gitmesini emrettiğinde o, 70 kişiyi seçip birlikte gittiler.” demektedir. ${ }^{98}$ Müfessir farklı yerlerde farklı açıklamalar yaparak bu hususta zihninin berrak olmadığını yansitmaktadir. ${ }^{99}$

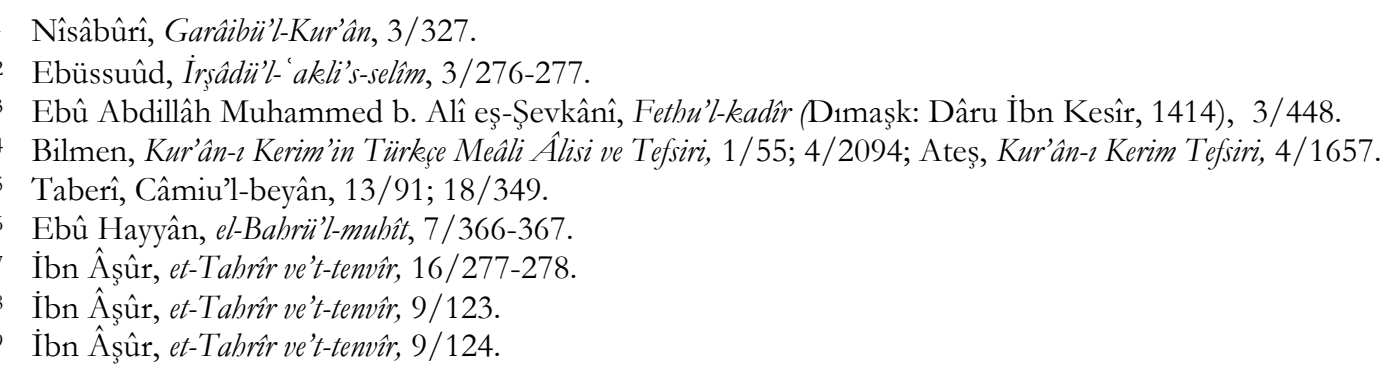


Mevdudi, "Hz. Mûsâ Rabbini görme hevesiyle mümkün olduğu kadar çabuk varabilmek için yolda İsrâiloğullarından ayrılmış ve buluşma yerine yalnız ulaşmıştır." ${ }^{100}$ demektedir. Diyanet Tefsirinde, "kavminden” kastın İsrâiloğulları olduğu yazılmaktadır. ${ }^{101}$ Müfessirlerden farklı olarak İbn Âşûr, buzağıyla ve mîkâtla ilgili bilgilerin Tevrât’ta da geçtiğini yazmış; Diyanet tefsirinde de Tevrât'taki ifadeler özetlenmiştir. ${ }^{102}$

Görüldüğü üzere müfessirler, "kavim” ve “izimdeler” ifadelerine farklı anlamlar vermektedirler. Ancak Kur'ân'ın kıssadan bahseden bütün âyetleri birlikte değerlendirildiğinde kast edilenlerin bütün İsrâiloğulları olduğu anlaşılmaktadır.

2) " Iffadesi:

"أَثَرِي (peşimdeler/izimdeler) kelimesinin lügat manası incelendiğinde, kelimenin hakiki

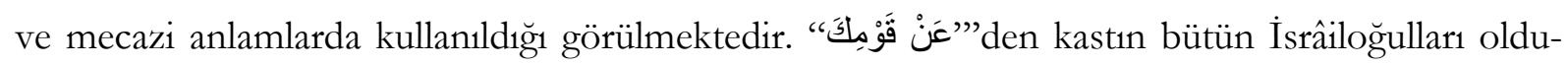
ğunu söyleyenler “"ثَلي اثري" ifadesini tefsir ederken iki gruba ayrılmışlardır.

Burada tartışmanın odağındaki اثر kelimesinin lügat anlamını ve onun Kur'ân'daki kullanımını incelemekte fayda vardır. Cevherî (ö. 400/1009), İsfahânî (ö. 502/1108) ve İbn Manzûr, ثر kelimenin, "kılıç kabzasının cilası, bir şeyin şeklinden kalan iz, geçmişten bir şeyi nakletmek, iyileşen yaranın kalan izi, k1lıç yarasının izi, izini sürebilmek için devenin ayak tabanına takılan demir, Peygamber’in sîreti, peşinden gitmek, bir şeyi başkasına tercih etmek” manalarına geldiğini yazmıştır. ${ }^{103}$ Kelime Kur'ân'da ise "iz"104, "yolunda, izinde"105 ve "arkasında/peşinde"106 anlamında geçmektedir. ${ }^{107}$ Görüldüğü gibi “ثر” kelimesinin fiziksel ve manevi takip olmak üzere iki manas1 vardir.

Mâturîdî, "bazıları Hz. Mûsâ bir grupla çıkmadı, kavmini bırakıp tek başına gitti, demişlerdir. Bunlara göre, "onları yolum ve dinim üzere bıraktım, demektir. Hasan-1 Basri ve Katâde bu

100 Ebü’l-A'lâ Mevdûdî, Tefhimu'l-Kur'ân (İstanbul: İnsan Yayınları, 1997), $3 / 265$.

101 Hayreddin Karaman \& Mustafa Çağrıcı \& İbrahim Kâfi Dönmez \& Sadrettin Gümüş, Kur'an Yolu Türkese Meal ve Tefsir (Ankara: Diyanet İşleri Başkanlığı Yayınları, 2007), 3/647.

102 İbn Âşûr, et-Tabrîr ve't-tenvîr, 9/124; Karaman, 3/647-648; 1/123-127; 2/598-599.

103 Ebû Nasr İsmâil b. Hammâd el-Cevherî, es-Sıbâh tâcü'l-luga ve sıhâhu'l-arabiyye (Beyrut: Dâru'l-ilm li'l-melâyîn, 1407/1987), 2/574-575; Ragib el-İsfahânî, el-Müfredât fî garîbi'l-Kur'ân, thk. Safvân Adnân ed-Dâvudî, 1. Bask1 (Dımaşk: Dâru'l-kalem, 1412), 1/62; Ebü'l-Fadl Cemalüddîn b. Manzûr, Lisânu'l-Arab (Beyrut: Dâru sâdır, ts.), 4/5-8.

104 Bk: el-Ahkâf 46/4; el-Fetih 48/29; el-Âdiyât 100/4.

105 Bk: et-Tâhâ 20/96.

106 Bk: el-Mâide 5/46; el-Keyf 18/6, 64; et-Tâhâ 20/84; er-Rûm 30/50; el-Yâsîn 36/12; es-Sâffât 37/70; ez-Zuhruf 43/22-23; el-Hadîd 57/27.

107 Kelime ayrıca أَثَارُ (kazmak) şeklinde de geçmektedir. Bk.: er-Rûm 30/9; el-Mü’min 40/21, 82. 
görüştedir.” demektedir. ${ }^{108}$ İbn Ebî Zemenîn (ö. 399/1008), “عَلي اثري" derken Hz. Mûsâ’nın “onlara götüreceğim şeyi bekliyorlar" dediğini ve takip etmeyi kastetmediğini, belirtmektedir. ${ }^{109}$

Nehhâs (ö. 338/950), Mekkî ve İbn Atiyye (ö. 541/1147), علي اثري ifadesinden kavminin peşinden gitmesini istediği ve onları kast ederek, "bana yakınlar" dediği, görüşündedir. ${ }^{110}$ İbn Kesîr, “" "عeliyorlar, Tûr'a yakın bir yerde konakladılar.”"111 demektedir. Ayrıca Nesâ̂̀nin Sünenü’l-Kübrâ'sında ve başka hadis kitaplarında geçen ve Bûsîrînin (ö. 840/1436) de sahih olarak kabul ettiği “Fitneler Hadisi'ni” İbn Abbâs'tan Saîd b. Cübeyr tarikiyle nakletmektedir. Orada Hz. Mûsâ’nın, İsrâiloğullarını bir yere yerleştirdikten sonra Hz. Hârûn'u kavminin başında vekil bırakarak Tûr’a yalnız gittiği yazılmaktadır. ${ }^{112}$ Taberî bu rivâyetin sadece baş kısmını aktarmaktadir. ${ }^{113}$

Taberî ve İbn Kesîr, el-Bakara 2/55. âyetle ilgili tevbe etmek üzere gidenler hakkında Katâde ve Rebî' İbn Enes’ten şunu nakletmektedir: "Bunlar Hz. Mûsâ'nın tevbe etmek için seçmiş olduğu 70 kişidir. Onlar Hz. Mûsâ ile beraber gittiler ve bir ses işittiler. Bunun üzerine, "Allah'ı açıkça görünceye kadar sana inanmayız.” dediler.”114 Bu rivâyette Hz. Mûsâ’nın Tûr'a ikinci gidişinde 70 kişiyle olduğu ifade edilmektedir.

İbn Ebî Hâtim (ö. 327/938), Hâkim (ö. 405/1014), İbn Kesîr, Suyûtî ve Şevkânî, Hz. Ali'den (ra) şunu nakletmişlerdir: "Hz. Mûsâ Rabbine gitmekte acele etmişti. İşte o zaman Sâmirî kalkmış, İsrâiloğulları kadınlarının süs eşyalarından güç yetirebildiklerini toplamış, ona böğüren buzağı heykeli şekli vermişti. Sonra da: "Bu sizin de Mûsâ'nın da tanıısıdır" demişti. Hz. Hârûn onlara: "Ey milletim! Rabbiniz size güzel bir va ‘dde bulunmadı mı?” demişti. Hz. Mûsâ (Tûr'dan dönüşünde) buzağıya yönelmiş, onu eğeyle yontup ufalamıştı. $O$, nehrin kenarında imiş. Buzağıya tapanlardan bu sudan kim içmişse yüzü altın gibi sararmış. İsrâiloğulları Mûsâ'ya: Bizim tevbemiz nedir? diye sormuşlar. O da: "Birbirinizi öldürmenizdir." demiştir."115

\footnotetext{
108 Mâturîdî, Te’vîlât, 7/298-299.

109 Ebû Abdillâh İbn Ebû Zemenîn, Tefsiru'l-Kur'âni'l-ąî́ (Kahire: el-Fârûku'l-hadîse, 2002), 3/122.

110 Ebû Cafer en-Nehhâs, I' râbu'l-Kur'ân (Beyrut: Dâru'l-kutubi'l-ilmiyye, 1421), 3/37; Mekkî, el-Hidâye, 7/4679-4681; İbn Atiyye, el-Muharrerü'l-vecî́, 4/57.

111 İbn Kesîr, Tefsiru'l-Kur'ân, 3/170.

112 Ebû Abdirrahmân en-Nesâî, es-Sünenü'l-kübrâ (Beyrut: Müessesetü'r-risâle, 2001), 10/172; Ebü'l-Hasen Nûrüddîn Alî b. Ebî Bekr el-Heysemî, el-Makșadü'l-alî fî zevầidi Ebî Ya 'lâ el-Mevsılì, thk. Seyyid Kisrevî Hasan (Beyrut: Dâru'l-kutubi'l-ilmiyye, 1413/1993), 3/96; Ebü'l-Abbâs Şihâbüddîn Ahmed el-Bûsîrî, İthâfü'l-bryere bi-z̧evâ'idi'lmesânîdi'l-aşere (Riyad: Dâru'l-vatani li’n-neşr, 1999/1420), 6/244; İbn Kesîr, Tefsiru'l-Kur'ân, $3 / 159$.

113 Taberî, Câmin'l-beyân, 16/64.

114 Taberî, Câmiu'l-beyân, 2/86-88; 13/140; İbn Kesîr, Tefsiru'l-Kur'ân, $1 / 97$.

115 İbn Ebî Hâtim, Tefsîru'l-Kur'âni'l-azîm, thk. Esad Muhammed et-Tayyib, 3. Baskı (Suûdi Arabistan: Mektebetü Nezzâr Mustafa el-Bâz, 1419), 1/111; 7/2430; Hâkim en-Nîsâbûrî, el-Müstedrek alâ sabîhayn, thk. Mustafa Abdul-
} 
Hâkim bu rivâyetin sahih olduğunu ve Buhârî ile Müslim’in şartlarını taşıdığını söylemektedir. ${ }^{116}$ Ancak Zehebî’nin de belirttiği gibi Müstedrek’teki hadislerin önemli bir kısmı Buhârî ve Müslim'in şartlarını taşımamaktadır. ${ }^{117} \mathrm{Bu}$ hadisin mevkuf olması, "nehrin kenarında olmak" ile "parçalanan buzağının atıldığı suyun kavme içirilmesi” ifadelerinin Tevrât'la örtüşmesi ve Kur'ân'la çelişmesi, rivâyeti sorunlu kılmaktadır. Ayrıca açıkça Hz. Mûsâ’nın Tûr’a birinci gidişini bildiren âyette geçen ifadeyi, ikinci gidişteki 70 kişiyle olması şeklinde anlamlandırması Kur'ân'la bağdaşmamaktadır. Nitekim Elmalılı, el-A'râf 7/155. âyetini tefsir ederken: "Bu miykata da bundan evvel geçen miykatı kelâm diyenler olmuşsa da gerek Kur'ân'da iki kıssanın fasl-ü tefrikına ve gerek bâ'zı rivayata nazaran bunun ıcıl vak'asından sonra tevbe için diğer bir miykat olduğu anlaşılıyor.”118 diyerek müfessirlerin fikir karışıklığını gidermeye çalışmışıır.

Görüldüğü gibi müfessirlerin çoğunluğu İsrâiloğullarının veya 70 kişilik grubun $\mathrm{Hz}$. Mûsâ’nın arkasında yürümekte olduğu görüşündedir. Az sayıda müfessir ise " على izimdeler tabiriyle manevi takip kast edildiği, kavminin kendisinin yolunda olduğunu, kendilerinden aldığ1 ahit üzere hayatlarını sürdürdüklerini” ifade ettiği kanaatindedir. Oysa Hz. Mûsâ “"على " ifadesiyle şu sebeplerden ötürü 70 nakibi kast etmiş olamaz:

I- Hz. Mûsâ 'Tûr'a birincisinde Tevrât'ı almak için yalnız; ikincisinde ise tevbe etmek için seçilen 70 kişiyle gitmiştir. Allah'ın Tevrat'ı almak üzere giden Hz. Mûsâ ile bu konuşması birinci gidişte gerçekleştiğine göre onun 70 nakibi kast ederek "arkamdan geliyorlar" demesi vakıaya uygun değildir.

II- Âyetlerden anlaşıldığı üzere Hz. Mûsâ'nın ayrılmasından sonra İsrâiloğullarının buzağıya tapacakları kadar bir zamanın geçmiş olması gerekmektedir. Bu da, Hz. Mûsâ’nın Tûr'a geldikten birkaç gün sonra bu konuşmanın gerçekleşmiş olmasını zorunlu kılmaktadır. Bu durumda onun acele etmesinin gerekçesi olarak “arkamdan geliyorlar” savunmasının makul bir tarafı olamaz. Zira birkaç günde hemen arkasından gelmekte olan 70 nakibin ona mutlaka ulaşmış olması gerekmektedir. Böyle bir durumda da Hz. Mûsâ’nın bu gerekçeyi ileri sürmesi mantıklı gözükmemektedir.

Peki, Hz. Mûsâ “تَلثي" ifadesiyle "İsrâiloğullarının arkasından gelmekte olduğunu” neden kast etmiş olamaz? Hz. Mûsâ İsrâiloğullarını Tûr’un sağ yanına yerleştirdikten sonra onlar-

kâdir Atâ, 1. Bask1 (Beyrut: Dâru'l-kutubi'l-ilmiyye, 1411/1990), 3434, 2/411; Celaleddîn es-Suyûtî, ed-Dürrü'lmensûr (Beyrut: Dâru'l-fikr, ts.), 5/592; İbn Kesîr, Tefsiru'l-Kur'ân, 1/330; Şevkânî, Fethu'l-kadîr, 3/451.

116 Hâkim, el-Müstedrek, 3434, 2/411.

117 Muhammed b. Ahmed ez-Zehebî, Siyeru a'lâmi'n-nübelâ (Kahire: Dâru’l-hadîs, 2006), 12/577.

118 Elmalı'li, Hak Dini, 4/2292. 
dan kendi yokluğunda sapmamaları için kesin söz almıştı. Ayrıca Hârûn’a (as) sık1 sıkı tembihlerde bulunarak kavmin başında bulunmasını ve emirlerine riayet etmesini istemişti. Bu durum, el-A'râf 7/142 ile et-Tâhâ 20/92-94. âyetlerinde anlatılanlar ve yukarıda bahsedilen "Fitneler Hadisi" İsrâiloğullarının Hz. Mûsâ’nın arkasından Tûr’a çıkmak üzere yürümediklerini göstermektedir.

Allah'ın Hz. Mûsâ ile konuşmasının kırk günlük randevunun hangi zaman aralığında gerçekleştiği âyetlerde belirtilmemektedir. Ancak âyetler tahlil edildiğinde üç ayrı zamanda üç farklı konuşmanın gerçekleştiği anlaşılmaktadır.

İlk konuşma, Hz. Mûsâ'nın Tûr-i Sina’ya geldikten bir süre sonra gerçekleşen şu ifadelerdir: "(Allah): Mûsâ, seni kavminden çabuk gelmeye sevk eden nedir?" dedi. Mûsâ: "Onlar izimdeler, Rabbim! Hoşnut olman için Sana acele geldim" dedi. Allah: "Doğrusu Biz, senden sonra milletini sınadık; Sâmirî onları saptırdı." dedi."

Bu konuşma Hz. Mûsâ'nın, İsrâiloğullarından ayrıldıktan otuz gün sonra gerçekleşmiş olması kuvvetle muhtemeldir. Zira onların ziynet eşyalarından ve mücevherlerden kurtulma isteklerinin gündeme gelmesi ve Hz. Mûsâ'nın dönmesine de vakit olması gerekmektedir. Sâmirî̀nin mücevherleri eritip şekle dönüştürmesi için de bir vaktin; buzağı yapıldıktan sonra İsrâiloğullar1nın bunun etrafinda toplanıp Hz. Hârûn'a başkaldıracakları, Hz. Mûsâ'yı unutkanlıkla itham edecekleri bir zamanın geçmesi lazımdır. Bu da üç-beş günle sınırlandırılamayacak kadar uzun olmalıdır. Hz. Mûsâ'nın "Uzun bir zaman mı geçti?’"120 ifadesinden biraz zamanın geçtiği, ancak bunun peygamberin yolundan sapmalarını ve onu unutmalarını gerektirecek kadar uzun bir müddet olmadığı anlaşılmaktadır.

İkinci konuşma, muhtemelen otuz ile kırk günlük sürenin ortalarında iken el-A'râf 7/143144. âyetlerde haber verilen Hz. Mûsâ'nın Allah’ı görme isteğinin gerçekleştiği konuşmadır. Bu esnada Hz. Mûsâ ağır bir imtihandan geçmiş ve baygin düşmüştür.

Üçüncü konuşma ise muhtemelen kırk günlük sürenin bitimine yakın bir zamanda, Tevrât'ın levhalarının verilmesinden sonra gerçekleşen şu konuşmadır: "Ey Mûsâ! Verdiklerimle ve seninle konuşmamla seni insanlar arasından seçtim; sana verdiğimi al ve şükret" dedi. Ona levhalarda her şeyden bir öğüt yazdık ve her şeyi uzun uzadıya açıkladık; onlara sıkıca sarıl, milletine de emret, en güzel şekilde tutsunlar. Size Allah'a karşı gelenlerin yurdunu göstereceğim."’121

\footnotetext{
119 et-Tâhâ 20/83-85.

120 et-Tâhâ $20 / 86$.

121 el-A'râf 7/144-145.
} 
Müfessirler, Allah'ın Hz. Mûsâ ile konuşmasının gerçekleştiği zaman dilimi hakkında da farklı görüşler ileri sürmüşlerdir. Taberî, İbn Cüreyc'den Sâmirî̀nin, buzağıyı son on günde yaptığını ve insanları ona tapmaya davet ettiğini nakletmektedir. ${ }^{122}$ Buna göre konuşma son on günde gerçekleşmiştir. Zemahşerî, İ̉bn Abbâs’tan (ra) naklen Yüce Allah'ın Hz. Mûsâ ile 40 gün 40 gece konuştuğunu, قيل lafzıyla da bu konuşmanın 40 günün başlarında, ${ }^{123}$ başka bir yerde ise yine lafzıyla son on günde; ${ }^{124}$ Nîsâbûrî, “Acele ettiren nedir?” hitabının Hz. Mûsâ’nın Tûr’a gelişinin başlarında gerçekleştiğini söylemektedir. Ancak “ فَرَجَعَ مُوسى ifadesindeki “"ف”"nin takibiye olduğunu ve bu konuşmanın dönüş zamanında gerçekleştiğini” söyleyenlerin varlığından da bahsetmektedir. ${ }^{125}$ Hâzın, buzağıya tapmanın 20 . veya 30. günden sonra gerçekleştiğini söylemektedir. ${ }^{126}$ Elmalıl1, "öyle anlaşllyyor ki ilk otuz gün savm ve sâir tekarrubât ile bir tehzibi mahsus ve bir riyazât olmuş ve sonraki on günde de Tevrât'ın nüzulü ve kelâm vuku' bulmuştur."127 demektedir.

Hz. Mûsâ'yla olan 30 gecelik vadenin 40 geceye çıkartılması İsrâiloğulları ve Sâmirî için imtihanın unsurlarından biridir. Gecikmenin bir fitne aracina dönüşmesinden ötürü buzağıya tapınma hadisesinin vadenin son 10 gününde gerçekleştiği sonucu çıkmaktadır. Bu da Hz. Mûsâ’nın "arkamdan geliyorlar" deme ihtimalini ortadan kaldırmaktadır. Zira böyle bir durumda onların kendisine yetişmiş olması gerekmektedir.

d) Tevrât'ta halkın, Mûsâ'nın (as) geciktiğini görmesi üzerine Hârûn'dan bir ilâh yapmasını istediği, onun da ziynetleri toplayıp altın bir buzağı yaptığı, İsrâiloğullarına uyduğu ve onları puta tapmaya çağırdığı ifade edilmektedir. Kur'ân'da buzağıyı yapanın Sâmirî olduğu; Hz. Hârûn’un onlara karşı çıktı̆̆ı, 1srarla uyarıda bulunduğu fakat tehdit edilmesi üzerine fitnenin çıkmaması için uyarmaktan vazgeçtĭği belirtilmektedir. İbn Kesîr, "İsrâiliyyât kitaplarında zikredildiğine göre Sâmirî'nin ismi Hârûn imiş." derken ${ }^{128}$ Mevdûdî, "Sâmirî'nin gerçek adının Hârûn olması, İsrâiloğullarının daha sonraları bunu Peygamber Hârûn (as) ile karıştırmış olmaları mümkündür.” kanaatindedir. ${ }^{129} \mathrm{Bu}$ açıklamalar, peygamberlerin ismet sıfatıyla örtüşmektedir.

122 Taberî, Câmiu'l-beyân, 13/88-89.

123 Zemahşerî, el-Keş̧âf, 2/152.

124 Zemahşerî, el-Keşşaf, 2/151.

125 Nîsâbûrî, Garâibü'l-Kur'ân, 4/564.

126 Hâzin, Lübâb, 1/46.

127 Elmalı'lı Muhammed Hamdi Yazır, Hak Dini Kur'an Dili (İstanbul: Eser Neşriyat, ts.), 4/2275.

128 İbn Kesîr, Tefsiru'l-Kur'ân, 5/310.

129 Mevdûdî, Tefhîm, 3/269. 
e) Kur'ân'da Hz. Mûsâ’nın dağdan inişi esnasındaki halkın durumundan bahsedilmez. Tevrât'ta buzağıya tapanların hâlâ kutlama yaptıkları ve çalgılar eşliğinde sevinç naraları attıkları anlatılmaktadır. Sa 'lebî, kaynak belirtmeden, İsrâiliyâtın etkisiyle kutlamalardan bahsetmektedir. ${ }^{130}$

f) Kur'ân, Hz. Mûsâ döndüğünde “levhaları attı” demektedir. Tevrât, Hz. Mûsâ’nın levha-

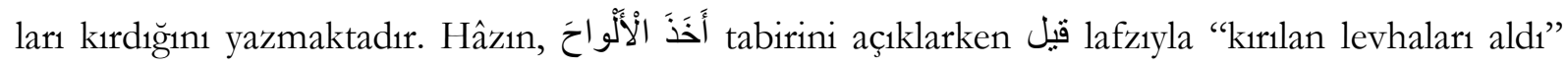
görüşünü nakletmektedir. ${ }^{131}$ Zemahşerî ve Elmalılı ise, "Denilmiş ki bırakılınca elvah kırılmış ve binaenaleyh yedide altısı ref' olunmuş ancak biri kalmıs." ${ }^{\text {132 }}$ demekte ancak buna herhangi bir kaynak vermemektedir.

g) Kur'ân'da buzağı heykelinin yakıldığı ve tozlarının "denize” atıldığ1 belirtilmekte iken Tevrât'ta Hz. Mûsâ’nın buzağıyı yaktığı, toz haline gelinceye dek ezdiği, sonra onu “derenin suyu-

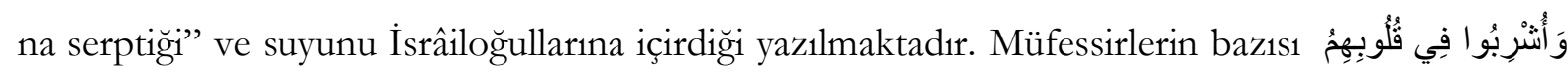
“İkârlar1 yüzünden buzağ1 sevgisi kalplerine sindirildi."” Tevrât'ın ifadelerini esas almışır. Yukarıda geçtiği gibi İbn Ebî Hâtim, İbn Kesîr, Suyûtî ve Şevkânî, Hz. Ali'den (ra) bu manada nakilde bulunmuştur.

Taberî âyete ilk önce, "kalplerine buzağı sevgisi sindirildi” manasını vermiş ancak daha sonra Süddî ve İbn Cüreyc’ten şunu nakletmiştir: “Hz. Mûsâ buzağıyı törpü ile törpüledi ve onu suya serpti. İsrâiloğullarına da: "Haydi bu sudan içiniz." dedi. Hepsi o sudan içti. Dudaklarında törpülenen altının tozları belirdi." ${ }^{134}$ Mâturîdî, "kalplerine buzağı sevgisi içirildi” açıklamasını yaptıktan sonra قيل lafzıyla “törpülenen altın tozlarının atıldığı suyu buzağıya olan sevgilerinden dolayı içtiler." ${ }^{355}$ açıklamasını yapmaktadır. Mâverdî, Begâvî ve Alûsî, buna benzer açıklamalar yapmıştir. $^{136}$

Hz. Ali'nin Tevrât'ın ifadesine benzeyen yukarıdaki sözlerinin Ehli Kitap'tan hidayete eren birisinden alınma ihtimali yüksektir. Buna rağmen Kur'ân'da açıkça “denize attı” denilmiş olması-

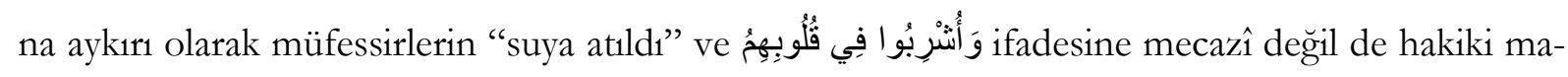

\footnotetext{
130 Sa'lebî, el-Kesf, 6/258.

131 Hâzin, Lübâb, 2/254.

132 Zemahşerî, el-Keş̧âf, 2/161; Elmalı'lı, Hak Dini, 4/2287.

133 el-Bakara 2/93.

134 'Taberî, Câmiu'l-beyân, 2/358.

135 Mâturî̀î, Te'vîlât, 1/512.

136 Mâverdî, en-Nüket, 1/160; Begavî, Me âlimü't-tenqîl, 1/143; İbn Atiyye, el-Muharrerü'l-vecîz, 1/180; Âlûsî, Rûhu'lmèâni, $1 / 326$.
} 
nayı vermiş olmaları bir hata olarak değerlendirilmelidir. Zira "kalbe içirilme" deyimi hakiki bir anlamda düşünülemez. Nitekim kanaatini belirten Taberî bunu açıkça da ifade etmektedir. ${ }^{137}$

h) Tevrât'ta meleğin gelip İsrâiloğullarına denizden çıarken rehberlik ettiği ${ }^{138}$ bir defa ise tevbe etmek üzere kavmini belirtilen yere götürmesi için Mûsâ’ya (as) öncülük ettiği haber verilmektedir. ${ }^{139}$ Kur'ân ise melekten bahsetmemekte, sadece Sâmirî’nin buzağının harcına من اثر "elçinin izinden”140 aldığı toprağı attı̆̆ı ifade edilmektedir.

Âyette geçen “"اثر الرسول" tabiri müfessirleri farklı yorumlara yöneltmiştir. Ebû Hayyân, “Hz. Mûsâ'nın sünneti ve uyulmasını emrettiği modelidir." demektedir. ${ }^{141}$ Ancak Mücâhid (ö. 103/721), Mukâtil, Taberî, Begâvî, İbn Atiyye, İbn Cevzî, Ebû Hayyân, Hâzın, Kurtubî, Suyûtî ve İbn Acîbe gibi birçok müfessir bu müphemliği Tevrât'nn, "İsrail ordusunun önünde yürüyen Tanri'nın meleği..." الرسول il142 ifadesinden esinlenerek “Cebâill” olarak açıklamıştır. ${ }^{143}$ Taberî, İbn

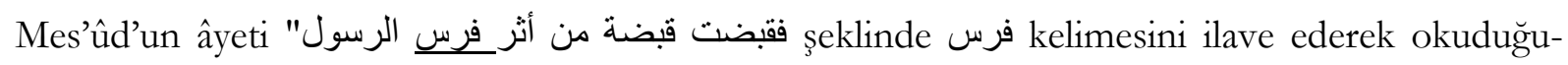
nu”; ${ }^{144}$ İbn Abbâs'ın (ra) ise "Cebrâil'in izi”" dediğini nakletmektedir. ${ }^{145}$

Âyette Hz. Mûsâ ile Sâmirî arasında geçen konuşmada "er-Resûl” denilerek 3. bir şahıstan bahsedilmektedir. Buradaki “elçinin” Cebrâil, “ayak izinden” ise hakiki manasıyla Cebrâil'in veya atının ayak izi kastedilmektedir. Müfessirlerin bu yorumuyla bir müphem vuzuha kavuşturulmuştur.

1) Tevrât'ta Hz. Mûsâ’nın puta tapan İsrâiloğullarını birbirlerini öldürmek üzere silahlanmaya çağırdığı ve Levililerin onun yanında yer alarak savaştıkları, akraba ve yabancı gözetmeksizin vuruştukları, 3 bin kişinin öldürüldüğü yazılmaktadır. Kur'ân'da herhangi bir çatşma ve öldürme eyleminden söz edilmemekte, Hz. Mûsâ’nın onları ikna ettiği, onlara yanlışlıklarını gösterdiği ve Allah'a dönmeye ve tevbe etmeye davet ettiği belirtilmektedir. Ayrıca Tevbe sûresi 153. âyeti onla-

137 Taberî, Câmiu'l-beyân, 2/358-359.

138 Bk: Çı1kış 14: 19-20.

139 Çıkış 32: 34.

140 et-Tâhâ 20/96.

141 Ebû Hayyân, el-Babrï'l-mubît, 7/376.

142 Çıkı̧ 14: 19.

143 Mücâhid b. Cebr el-Mahzûmî, Tefsîru Mücâhid, thk. Muhammed Abdusselâm Ebü'n-Nebîl (Misır: Dâru'l-fikri'lİslâmî el-hedîse, 1989), 1/343, 1/465; Mukâtil, Tefsîru Mukâtil, 3/38; Taberî, Câmiu'l-beyân, 2/64-68; 18/361; Begavî, Me âlimü't-tenzîl', 3/273; İbn Atiyye, el-Muharrerü'l-vecîz, 4/57; İbn Cevzî, Zâdü'l-mesîr, 3/174; Ebû Hayyân, elBabrü'l-mubît, 7/376; Hâzın, Lübâb, 1/45, 2/251, 3/211; Kurtubî, el-Câmi li-abkâm, 11/239; Suyûtî, ed-Dürrü'lmensûr, 5/596; İbn Acîbe, el-Babrü'l-medîd 3/415.

144 Taberî, Câmiu'l-beyân, 2/64.

145 Taberî, Câmiu'l-beyân, 18/362. 
rın buzağı heykeline taptıkları hâlde bağışlandıklarından bahsetmektedir. ${ }^{146}$ Tevbeden kaçınanların Allah'ın öfkesine uğrayacakları ifade edilmektedir.

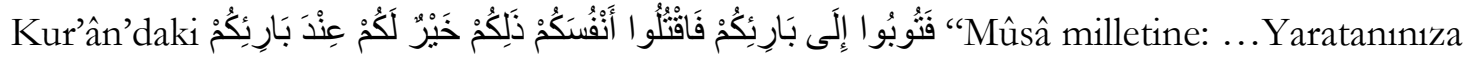
tevbe edin ve nefislerinizi öldürün, bu Yaratanınız katında sizin için hayırlı olur.”147 âyeti kerimesini tefsir eden bazı müfessirler, âyetin devamında Allah'ın onların tevbelerini kabul ettiğinden bahsetmesi nedeniyle فَافْتُكُو أَنْفُسَكُمْ ifadesini “nefislerinizi, arzularınızı yok edin”; bazı müfessirler ise

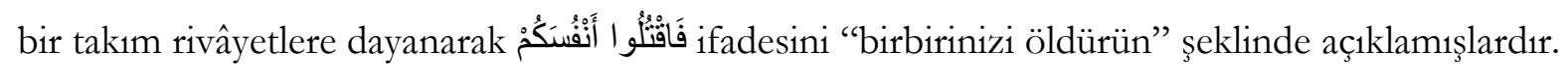

Nesâ̂i “es-Sünenü’l-kübrâ"da İbn Abbâs’tan (ra) şunu nakletmiştir: "İsrâiloğulları Hz. Mûsâ'ya: "Tevbemiz nedir?” diye sormuş. O da: "Birbirinizi öldürmenizdir." demiştir. Bunun üzerine hançerlerini aldılar. Adam kimi öldürdügüne aldırmadan babasını, kardeşini öldürüyordu. Allah öldürülenleri de öldürenleri de affetti." ${ }^{148}$ İbn Ebî Hâtim ve Hâkim, Hz. Ali'den (ra) şunu rivâyet etmiştir: "İsrâiloğulları Mûsâ'ya (as): "Tevbemiz nedir?” diye sorunca o da: "Birbirinizi öldürmenizdir.” demiştir. Bunun üzerine hançerlerini aldılar. Adam kimi öldürdüğüne aldırmadan babasını, kardeşini öldürüyordu. Allah, Hz. Mûsâ’ya, "kılıçlarını bırakmalarını emret. Öldürülenleri affettim. Kalanların da tevbesini kabul ettim.” buyuruncaya kadar 70 bin kişi öldürüldü.” ${ }^{149}$

Taberî ve İbn Kesîr ise İbn Abbâs’tan (ra) şunu nakletmiştir: "Buzağıya tapınmayanlar ayağa kalktı, hançerlerini ellerine aldı, üzerlerine şiddetli bir karanlık çöktü, birbirlerini öldürüyorlard1. Karartı üzerlerinden ayrılınca 70 bin kişi öldürülmüştü. Öldürülenlerin de kalanların da tevbesi kabul olundu." ${ }^{150}$ Taberî ayrıca İkrime ve İbn Cüreyc tarikiyle İbn Abbâs’tan (ra) ve Süddî’den 70 bin kişinin öldürüldüğünü nakletmektedir. ${ }^{151}$ Zemahşerî, Hâzın ve Elmalılı da 70 bin kişinin öldürüldüğünü söylemektedir. ${ }^{152}$

Tevrât'ta öfkelenen Allah'ı, İsrâiloğullarını cezalandırmaktan vazgeçiren Hz. Mûsâ’nın, onlara birbirlerini katlettirdiğinin yazılmış olması ve daha sonra da pişmanlık duyduğunun, halkın affedilmesi için Allah'a yakardığının belirtilmesi bir çelişkidir. Buzağı heykelini yaparak halkı puta tapmaya yönelten, onları açıkça teşvik ederek yoldan çıkaran Hârûn'a ceza verilmeyip ona uyanlardan Tevrât'a göre 3 bin, bu rivayetlere göre 70 bin kişinin öldürülmesini emretmek Allah'1n

146 Kayak, Tevrât ve Kur'ân'a Göre Sâmirî, 68.

147 el-Bakara 2/54.

148 Nesâî, es-Sünenü'l-kübrâ, 10/172; Heysemî, el-Maksadü'l-alî, 3/96.

149 Hâkim, el-Müstedrek, 3434, 2/411; İbn Ebî Hâtim, Tefsîru'l-Kur'ân, 1/111; 7/2430; Suyûtî, ed-Dürrü'l-mensûr, 5/592; İbn Kesîr, Tefsiru'l-Kur'ân, 1/330; Şevkânî, Fetbu'l-kadîr, 3/451.

150 Taberî, Câmiu'l-beyân, 2/73-74; İbn Kesîr, Tefsiru'l-Kur'ân, 1/262.

151 Taberî, Câmiu'l-beyân, 1/680; 1/683.

152 İbn Ebî Hâtem, Tefsiru'l-Kur'ân, 7/2431; Zemahşerî, el-Keşsâf, 1/140; Hâzın, Lübâb, 1/46-47; Elmalı'l1, Hak Dini, $1 / 355$. 
adaletine aykırıdır. Zira eğer birbirlerini öldürerek tevbeleri kabul edildiyse neden 70 kişinin seçilip Hz. Mûsâ'yla birlikte Tûr'a tevbe etmek için gitmeleri emredildi? Ayrıca Tûr'da 70 kişi helak edildiğinde müşfik bir edayla üç gün boyunca yakararak dua eden Hz. Mûsâ’nın tutumuyla, 70 bin kişi öldürülünceye kadar ses çıkartmadan izleyen Hz. Mûsâ’nın tavıı arasında da çelişki vardır.

Anlaşıldığı kadarıyla Hz. Ali'den (ra) ve İbn Abbâs’tan (ra) gelen rivâyetler Tevrât'taki 3 bin kişinin öldürülmesi bilgisinden daha ağır bir tablo ortaya koymaktadır. Bu da yukarıda da geçtiği gibi Hz. Ali'den (ra) ve İbn Abbâs'tan (ra) nakledilen bu bilginin Ehli Kitap'tan alınma ihtimalini güçlendirmektedir. Kur'ân'a göre Sâmirî̀ye bile şiddet uygulamayan ve sürgün cezasiyla yetinen, İsrâiloğullarına karşı metanetli, sabırlı ve affedici olan Hz. Mûsâ ve bağışlayan Allah ile Tevrât'taki şiddetli, intikamcı ve acımasız olan Allah ve öfkesi dinmeyen merhametsiz Mûsâ arasında belirgin bir tezat vardır. Müfessirlerin bunu gözden kaçıran açıklamalar yapması önemli bir kusurdur.

\section{Kıssanın Tefsirlere Yansımayan Tevrât ile Kur’ân'daki Farklılıkları}

Kıssanın her iki kutsal metinde bazı farklılıkları daha vardır fakat bunlar bu makalede inceleme konusu yapılan ve kaynakçada bilgileri verilen tefsirlere yansımamıştır. Bu farklılıkları şöyle sıralamak mümkündür:

a) Tevrât'ta Hz. Mûsâ'nın dağa çağrılması üzerine İsrâiloğullarının dağın eteğinde bir sunak kurdukları, İsrail'in on iki oymağını simgeleyen on iki taş sütun diktikleri, burada kurbanlar kestikleri ve kutlama yaptıkları belirtilmektedir. Kur'ân kutlamalardan bahsetmemektedir.

b) Kur'ân'da Allah'ın dağa tecelli ettiğinde onu yerle bir ettiği yazllırken; Tevrât'ta Hz. Mûsâ'nın dağdan indiği esnada dağın alev alev yandığı belirtilmektedir.

c) Tevrât'ta Allah'ın Hz. Mûsâ’ya parmağıyla yazmış olduğu iki taş levhayı verdiği ve levhaların içinde buyruklarının bulunduğu ifade edilmiştir. Kur'ân'da levhaların sayısından ${ }^{153}$ ve Allah’ın onları "parmağıyla yazdığından” bahsedilmemiştir. Onlarda "hidayet, rahmet, öğütler ve tafsilatlı bilgilerin” yazıldığına dikkat çekilmiştir.

d) Tevrât'ta, Allah'ın buzağıya tapmalarından ötürü öfkelendiği ve, "Bana engel olma, b1rak öfkem alevlensin, onları yok edeyim.”154 dediği ancak Hz. Mûsâ’nın Allah’1 ikna ettiği ve buna engel olduğu; Mûsâ'nın dağdan inince onları puta taparken gördüğ̈nde ise öfkeye kapıldığı belirtilmektedir. Kur'ân'da ise Hz. Mûsâ’nın dağdan öfkeli indiği yazılmaktadır. Ancak indikten sonra

153 Hasan el-Bâş, el- Kur'ân ve't- Tevrât eyne yettefikân ve eyne yefterikân (Beyrut: Dâru kuteybe, ts.), 1/262.

154 Çıııs 32: 10. 
bir tek Hz. Hârûn’a öfkeli davrandığı, İsrâiloğullarıyla görüşmesinde mantıklı hareket ettiği, ikna gücü yüksek bir konuşma yaptığı bildirilmektedir. Âyetlerde birinci mîkâtta Allah'ın kızgınlığını belirten herhangi bir ifade bulunmadığı gibi onların puta tapmalarının kendisinin bir imtihanı olduğu yazılmaktadır. Bir tek Hz. Mûsâ’nın dağdan indikten sonra İsrâiloğullarıyla yaptığı konuşmada, "Rabbinizin gazabının tepenize inmesini mi istiyorsunuz?" 155 dediği aktarılmaktadır.

e) Tevrât Hz. Mûsâ’nın ikinci mîkâtta da 40 gün 40 gece kaldığı belirtilirken Kur'ân süreden bahsetmemekte, Allah'ın isyankârlıkları nedeniyle 70 nakibin canını aldığını ve üç gün sonra tekrar dirilttiğini anlatmaktadır.

f) Hem Tevrât'ta hem de Kur'ân'da İsrâiloğullarına sahip çıkmadığı ve onları başıboş b1raktığı düşüncesiyle Hz. Mûsâ’nın Hz. Hârûn’a öfkelendiği, onun da "öfkelenme" dediği yazılmaktadır. Kur'ân'da onun İsrâiloğullarına söz geçiremediği ve üzgün olduğu, Hz. Mûsâ’nın onun için de Allah'tan af istediği belirtilmektedir. Tevrât'taki put yapan, onları buna tapmaya teşvik eden, hatta sunakta kutlama yaptıran Hz. Hârûn ile altın buzağıya tapmalarından dolayı üzgün ve pişman olan, bütün çabasına rağmen halkı engelleyemeyen ve son olarak da Hz. Mûsâ’yı sükûnete davet eden Hz. Hârûn karakteri arasında tezat bulunmaktadır.

g) Kur'ân'da Hz. Mûsâ’nın, İsrâiloğullarını puta tapmaya sürüklemesinden ötürü Sâmirî’yi; Tevrât'ta ise aynı fiili işleyen Hârûn'u (as) sorguladığı; Kur'ân'da Sâmirî̀nin sürgün edildiği; Tevrât'ta ise Hârûn'a (as) verilen herhangi bir cezadan bahsedilmediği görülmektedir. Tevrât'taki İsrâiloğullarına birbirlerini öldürten Hz. Mûsâ'nın tutumu ile asıl fail olarak onları saptıran ve azdıran, bunun sonucunda da Allah'ı kızdıran Hârûn'a bağırmanın dışında bir cezalandırmada bulunmayan Hz. Mûsâ'nın tutumu arasında çelişki vardır. Hatta onun Hz. Hârûn için Allah’a dua ederek af dilediği görülmektedir. Hârûn'la (as) ilgili bu iki farklı tutum, Hz. Mûsâ'nın kardeşi olan ve halife bırakılan Hz. Hârûn ile altın buzağıyı yapan ve halkı puta tapmaya çağıran Hârûn'un, bazı müfessirlerin de dikkat çektiği gibi aynı isimli farklı kişiler olduğu ihtimalini güçlendirmektedir.

\section{Sonuç}

Sâmirî kıssasının Kur'ân’da Tâhâ sûresi 20/83-98. âyetler, A'râf sûresi 7/138-155. âyetler, Bakara sûresi 2/51-56. âyetler ile Nisâ sûresi 4/152-153. âyetlerde; Tevrât'ta ise Çıkış 19, 24 ve 32, Yasa'nın Tekrarı (Tesniye) 9 ile Nehemya 9. bölümlerinde geçtiği görülmektedir. Her iki kitapta

155 et-Tâhâ 20/86. 
da kıssanın özünü tevhid inancının oluşturduğu ve İsrâiloğullarının vefasızlığından ve puta tapmaya meyilli tutumlarından bahsedildiği anlaşılmaktadır.

Kıssanın ayrıntılarında iki kitap arasında bazı benzerlikler ve farklılıklar olduğu tespit edilmiştir. Bu farklılıkların ilk dönemlerden itibaren müfessirleri etkilediği; Kur'ân'daki kıssanın bazı kelime ve ifadelerinin doğru anlaşılması için sahabeden itibaren ulemanın İsrâiliyyât'a veya Tevrât'a müracaat ettiği anlaşılmaktadır. Yapılan bu alıntıların bazen bir müphemi açıkladığı ve Kur'ân'la çelişmediği görülmektedir. Ancak tevbe etmek için seçilen 70 nakibin Tevrât'ı almak için gidildiğinde de Mûsâ’ya eşlik ettiğinin, Tûr'un başını dumanın sardığının, İsrâiloğullarının Allah'ın konuşmasını duyduğunun, buzağının tozlarının atıldığı suyun İsrâiloğullarına içirildiğinin tefsirlerde yazılması müfessirlerin Kur'ân'la bağdaşmayan yorumlarından olduğu anlaşılmaktadır.

Âyetlerde geçen هم علي اثري tabiriyle عن قومك ifadesinin çelişkiye düşmede odak noktasını

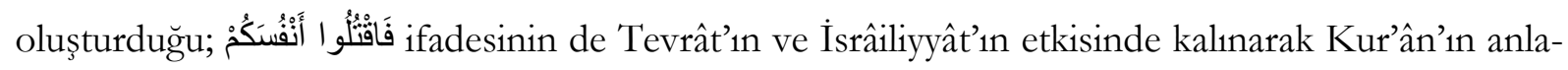
tımıyla örtüşmeyecek şekilde açıklandığı tespit edilmiştir. Bunların dışında da Kur'ân, Mûsâ’nın (as) buzağıya tapan İsrâiloğullarını sükûnetle ikna etmeye çalıştığı, herhangi bir silahlandırmadan ve öldürmeden bahsetmediği, aksine tevbelerinin kabul edilerek bağışlandıklarını haber vermesine rağmen 70 bin kişini öldürüldüğünün tefsirlerde rivâyet edilmesi; Hz. Mûsâ'nın Tevrât'ın levhalarını atıp kırdığının; parçalanan buzağının tozlarının dereye atıldığının yazılması müfessirlerin Kur'ân'la çelişen ifadeleri olduğu görülmüştür. Hz. Mûsâ'nın Tevrât'1 almak için Tûr'a ilk defa yalnız gidişiyle tevbe etmek için 70 nakible gidişinin Tevrât'ın etkisinden kalınarak karıştırıldığı, ilk seferde de yanında 70 kişinin bulunduğu iddiasının ifadelerine yansıdığı tespit edilmiştir.

Müfessirlerin Tevrât'ta geçen ifadeyi bazen aynen alıntı yaptıklanı hâlde Tevrât'a atıfta bulunmadıkları, bazen قيل lafzıyla kaynak belirtmeden aktardıkları, bazen de oradaki ifadeleri veya benzerlerini İbn İshak, Süddî, Rebî‘ b. Enes, İbn Zeyd ve Katâde’den, Taberî ve İbn Kesîr dışında herhangi bir kritik yapmadan rivâyet ettikleri görülmektedir. Ayrıca Hz. Ali (ra) ve İbn Abbâs'tan nakledilen mevkûf rivâyetlerin de içerik olarak Kur'ân'la örtüşmediği anlaşılmaktadır.

Yapılan nakillerin kaynağının belirtilmemesi, takip eden asırlarda yazılan tefsirlerde de çelişkilerin sürdürülmesine yol açtığı sonucuna varılmıştır. Tefsirlerdeki İsrâiliyyât'ın tam olarak ortaya çıkarılabilmesi için Kur'ân'daki diğer kıssaların da klasik ve modern dönem müfessirlerin açıklamalarının Tevrât, İncil ve diğer dini metinlerle karşılaştırılması gerektiği kanaatine ulaşılmıştır. 


\section{Etik Beyan / Ethical Statement:}

Bu çalışmanın hazırlanma sürecinde bilimsel ve etik ilkelere uyulduğu ve yararlanılan tüm çalışmaların kaynakçada belirtildiği beyan olunur / It is declared that scientific and ethical principles have been followed while carrying out and writing this study and that all the sources used have been properly cited.

Yazar(lar) / Author(s):

Selami YALÇIN

Finansman / Funding:

Yazar bu araştırmayı desteklemek için herhangi bir dış fon almadı̆̆ını kabul eder / The author acknowledges that he received no external funding in support of this research. 


\section{Kaynakça}

Âlûsî, Şehâbeddîn Mahmûd. Rûbu'l-me 'an̂̂ fî tefsîri'l-Kur'âni'l- 'ažim ve's-seb 'i'l-mesânî. Thk. Ali Abdulbârî Atiyye. 16 Cilt. Beyrut: Dâru'l-kutubi'l-ilmiyye, 1415.

Ateş, Süleyman. Kur'ânıı Kerim Tefsiri. 6 Cilt. Yeni Ufuklar Neşriyat, 1988/Milliyet, 1995.

Aydemir, Abdullah. Tefsirde Israiliyat. İstanbul: Beyan Yayınları, 2000.

Bâş, Hasan. el- Kur'ân ve't-Tevrât eyne yettefikân ve eyne yefterikân. Beyrut: Dâru kuteybe, ts.

Begavî, Ebû Muhammed el-Ferrâ. Me âlimü't-tenqૃ̂l. Thk. Abdurrezâk el-Mehdî. 8 Cilt. 1. Bask1. Beyrut: Dâru ihyâi't-turâsi'l-Arabî, 1420.

Beyzâvî, Nâsırüddîn Ebû Saîd Abdullah b. Ömer. Envâru't-teñîll ve esrâru't-te'vîl. 5. Cilt. Beyrut: Dâru'l-kutubi'l-ilmiyye, 1988.

Bilmen, Ömer Nasuhi. Kur'ân-ı Kerim’in Türkẹe Meâli Âlisi ve Tefsiri. 8 Cilt. İstanbul: Bilmen Yay1nevi, ts.

Bûsîrî, Ebü'l-Abbâs Şihâbüddîn Ahmed. İthâfü'l-hryere bi-z̧eva'idi'l-mesânîdi'l-așere. Riyad: Dâru'lvatani li’n-neşr, 1999/1420.

Büyük, Enes. “Tefsirde İsrâiliyyât'ın Arap Kültürüyle İlişkisi Üzerine Bir Araştırma”. Dinbilimleri Akademik Araștorma Dergisi XIV (2014), 91-107.

Cerrahoğlu, İsmail. Tefsir Tarihi. 2 Cilt. Ankara: Diyanet İşleri Başkanlığı Yayınları, 1988.

Cerrahoğlu, İsmail. Tefsir Usûüü. 10. Baskı. Ankara: TDV. Yayınları, 1995.

Cevherî, Ebû Nasr İsmâîl b. Hammâd. es-Sihâh tâcü'l-luga ve sıbâhu'l-Arabiyye. 6 Cilt. Beyrut: Dâru’lilm li'l-melâyîn, 1407/1987.

Ebû Hayyân el-Endelûsî. el-Babrü'l-mubit. Thk. Sıdkî Muhammed Cemil. 10 Cilt. Beyrut: Dâru’lfikr, 1420.

Ebüssuûd. İrşâdül-'akli's-selîm ilâ mezâya'l-Kitâbi'l-kerîm. 9 Cilt. Beyrut: Dâru ihyâi't-turâsi'l-Arabî, ts.

Elmalı'lı Muhammed Hamdi Yazır. Hak Dini Kur'an Dili. 10 Cilt. İstanbul: Eser Neşriyat, ts.

Ethem, Mürsel - Ünsal, Ramazan. "Kur'an'1 Anlamada İsrâliyat'in Rolü”. Pamukekale Üniversitesi İlahiyat Fakültesi Dergisi, 7 (2) (Güz/Autumn 2020): 1720-1744.

Hâzin, Ebü'l-Hasen Alâüddîn Ali b. Muhammed. Lübâbü't-te'vîl fî me âni't-tenæî̀l. 4 Cilt. Beyrut: Dâru'l-kutubi'l-ilmiyye, 1415.

Heysemî, Ebü’l-Hasen Nûrüddîn Alî b. Ebî Bekr. el-Maksadü’l-alî fî z̧evâidi Ebî Ya 'lâ el-Mevsilî. Thk. Seyyid Kisrevî Hasan. 4 Cilt. Beyrut: Dâru'l-kutubi'l-ilmiyye, 1413/1993. 
İsfahânî, Ragıb. el-Müfredât fî garîbi'l-Kur'ân. Thk. Safvân Adnân ed-Dâvudî. 1. Baskı. Dimaşk: Dâru'l-kalem, 1412.

Güllüce, Veysel. "Musa (as)'da İlahî Aşk”. Ekevv Akademi Dergisi. Yı1: 11, Sayı: 30 (Kış 2007): 75 84.

Hâkim en-Nîsâbûrî. el-Müstedrek alâ sahihayn. Thk. Mustafa Abdulkâdir Atâ. 4 Cilt. 1. Baskı. Beyrut: Dâru'l-kutubi'l-ilmiyye, 1411/1990.

İbn Acîbe, Ahmed, eş-Şâzelî. el-Bahrü'l-medîd fî tefsîri'l-Ķur'âni'l-mecîd. Thk. Ahmed Abdullah elKureşî. 7 Cilt. Kahire: Neşreden: Hasan Abbâs Zekî, 1419.

İbn Âşûr, Muhammed Tâhir. et-Tahrîr ve't-tenvîr. 30 Cilt. Tunus: Dâru't-Tunusiyye li’n-neşr, 1984.

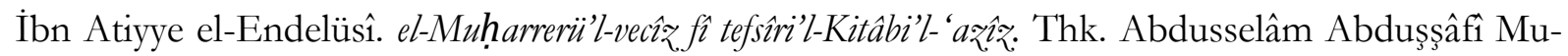
hammed. 6 Cilt. Beyrut: Dâru'l-kutubi'l-ilmiyye, 1422.

İbn Cevzî, Ebü'l-Ferec Cemâlüddîn. Zâdü’l-mesîr fì 'ilmi't-tefsîr. Thk. Abdurrezâk el-Mehdî. Beyrut: Dâru'l-kitabi'l-Arabî, 1422.

İbn Ebî Hâtim. Tefsîru'l-Kur'âni'l-aẑ̧̀m. Thk. Esad Muhammed et-Tayyib. 13 Cilt. 3. Baskı. Suûdi Arabistan: Mektebetü Nezzâr Mustafa el-Bâz, 1419.

İbn Ebî Zemenîn, Ebû Abdillâh. Tefsiru'l-Kur'âni'l-ą̧‡: 5 Cilt. Kahire: el-Fârûku'l-hadîse, 2002.

İbn Kesîr, Ebü'l-Fida İsmail. Tefsiru'l-Kur'âni'l-az̧im. 8 Cilt. Beyrut: Dâru'l-ma“rife, 1988.

İbn Manzûr, Ebü'l-Fadl Cemalüddîn. Lisânu'l-Arab. 15 Cilt. Beyrut: Dâru sâdır, ts.

Karaman, Hayreddin \& Çağrıcı, Mustafa \&Dönmez, İbrahim Kâfi \& Gümüş, Sadrettin. Kur'an Yolu Türkşe Meal ve Tefsir. 6 Cilt. Ankara: Diyanet İşleri Başkanlığ1, 2007.

Kayak, Fatih. Tevrât ve Kur'ân'a Göre Sâmir̂̂. Konya: Selçuk Üniversitesi, Sosyal Bilimler Enstitüsü, Yüksek Lisans Tezi, 2010.

Kurtubî, Ebû Abdillâh Muhammed b. Ahmed. el-Câmi ' li-abkâmi'l-Kur'ân. Thk. Ahmed el-Berdûnî ve İbrahim Atfişs. 20 Cilt. 2. Baskı. Kahire: Dâru'l-kutubi'l-Misriyye, 1384/1964.

Kuşeyrî, Abdulkerîm b. Hevâzin. Letâifü'-lişâaât. Thk. İbrahim el-Besyûnî. 3 Cilt. 2. Baskı. Mısır: el-Hey'etü'l-Misriyyetü'l-âmmeti li'l-kitâb, ts.

Mâturîdî, Ebû Mansûr. Te'vîlâtu ebli's-sünne. 10 Cilt. Beyrut: Dâru'l-kutubi'l-ilmiyye, 2005.

Mâverdî, Ebü'l-Hasen Ali b. Muhammed. en-Nüketü ve'l-'uyûn. 6 Cilt. Beyrut: Dâru'l-kutubi'lilmiyye, ts.

Mekkî b. Ebî Tâlib. el-Hidâye ilâ bulûgi'n-nihâye fî̀ ilmi meâni'l-Kur'ân ve tefsîribi. 13 Cilt. Câmiatu'şşârika-külliyetü’ş-şerîa ve dırâsâti'l-İslâmiyye, Mecmâatu buhûsi'l-kitab ve’s-sünne, 2008.

Meral, Yasin. Sâmirînin Buzağısı. Ankara: Ankara Okulu Yayınları, 2018.

Mevdûdî, Ebü'l-A'lâ. Tefbimu'l-Kur'ân. 7 Cilt. İstanbul: İnsan Yayınları, 1997. 
Mukâtil b. Süleymân. Tefsîru Mukâtil b. Süleymân. Thk. Abdullah Mahmud Şehâte. 5 Cilt. Beyrut: Dâru ihyâi't-türâsi'l-Arabî, 1423.

Mücâhid b. Cebr el-Mahzûmî. Tefsîru Mücâhid. Thk. Muhammed Abdusselâm Ebü’n-Nebîl. Misır: Dâru'l-fikri'l-İslâmî el-hedîse, 1989.

Nahcuvânî, Ni'metullah. el-Fevâtihu'l-ilâhiyye ve'l-mefâtibu'l-gaybiyye el-muvaddiba li'l-kelimi'l-Kur'ânîyye ve'l-bikemi'l-furkâniyye. 2 Cilt. Misır: Dâru rekâbî li'n-neşr, 1999.

Nehhâs, Ebû Cafer. İ râbu'l-Kur'ân. 5 Cilt. Beyrut: Dâru'l-kutubi'l-ilmiyye, 1421.

Nesâ̂i, Ebû Abdirrahmân. es-Sünenü'l-kübrâ. 10 Cilt. Beyrut: Müessesetü'r-risâle, 2001.

Nesefî, Ebü'l-Berekât Abdullah b. Ahmed. Medâriku't-teñîl ve hakâiku't-te'vîl. 4 Cilt. İstanbul: Kahraman Yayınları, 1984.

Nîsâbûrî, Nizâmuddîn. Garâibü'l-Kur'ân ve regâibü̈l-Furkân. Thk. eş-Şeyh Zekeriya Umeyrât. 6 Cilt. Beyrut: Dâru'l-kutubi'l-ilmiyye, 1416.

Râzî, Fahreddîn. Mefâtîhu'l-gayb, 32 Cilt. 2. Bask1. Beyrut: Dâru ihyâi't-turâsi'l-Arabî, 1420.

Sa'lebî, Ahmed b. Muhammed b. İbrahim. el-Kesf ve’l-beyân an tefsiri'l-Kur'ân. 10 Cilt. Beyrut: Dâru ihyâi't-turâsi'l-Arabî, 2002.

Semerkândî, Ebü'l-Leys. Bahrû'l-ulûm. 3. Cilt. (Şâmile).

Suyûtî, Celaleddîn. ed-Dürrül-mensûr. 10 Cilt. Beyrut: Dâru'l-fikr, ts.

Şevkânî, Muhammed b. Alî. Fethu'l-kadîr. 6 Cilt. Dımaşk: Dâru ibn Kesîr, 1414.

Taberî, Ebû Cafer Muhammed b. Cerir. Câmin'l-beyân an te'vili'l-Kur'ân. 24 Cilt. Beyrut: Müessesetu'r-risale, 2000.

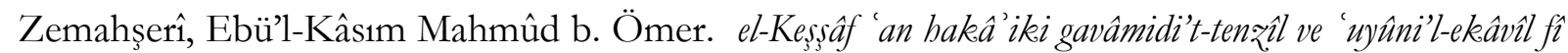
vücûbi't-te'vîl. 4 Cilt. Beyrut: Dâru'l-kutubi'l-Arabî, 1987.

Zehebî, Muhammed Hüseyin. et-Tefsîr ve’l-Müfessirûn. 2 Cilt. Beyrut: Daru ihyâi't-turasi'l-Arabî, 1976.

Zehebî, Muhammed b. Ahmed. Siyeru a 'lâmı’n-nübelâ. 18 Cilt. Kahire: Dâru’l-hadîs, 2006. 